
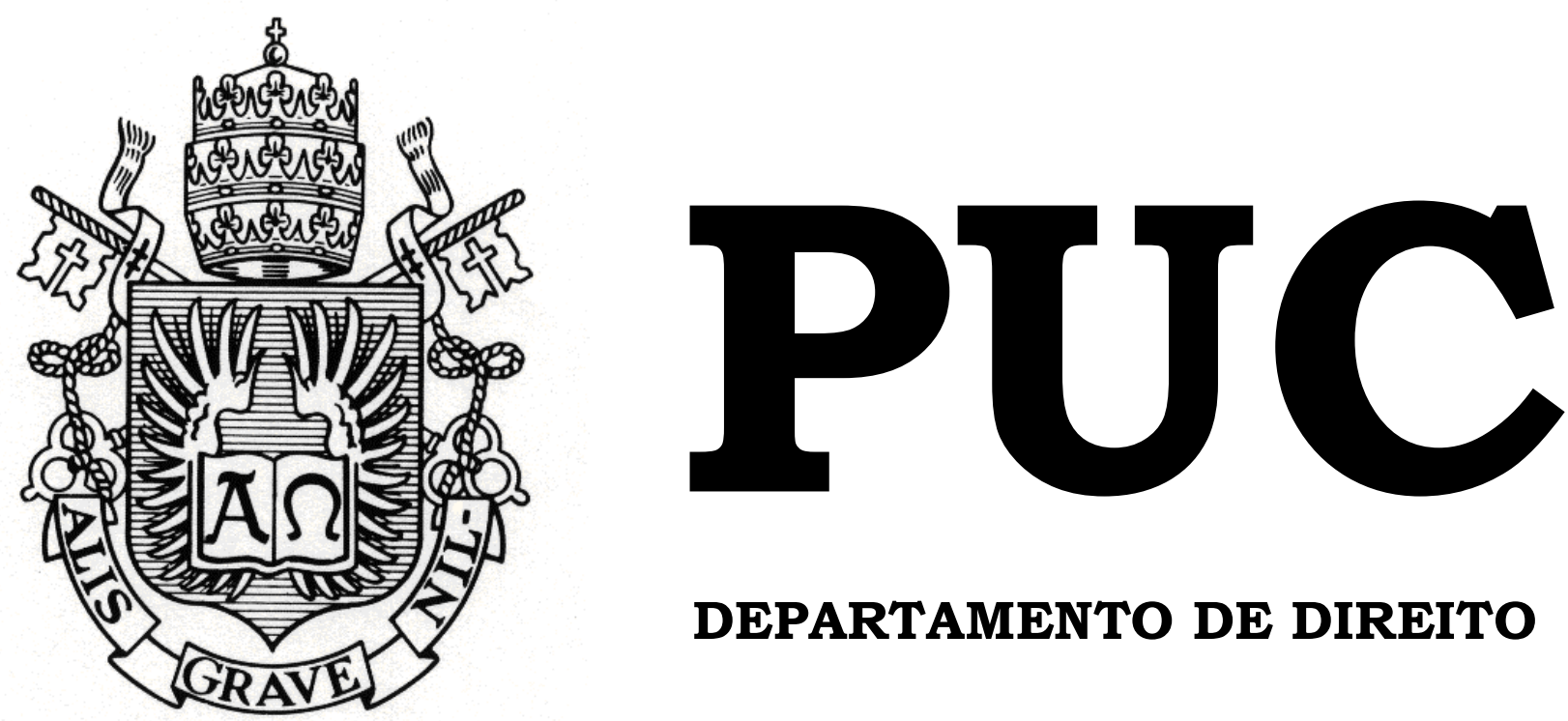

DEPARTAMENTO DE DIREITO

\title{
ASPECTOS AMBIENTAIS QUE ENVOLVEM A ATIVIDADE DE EXPLORAÇÃO E PRODUÇÃO DE PETRÓLEO
}

por

MARIA HELENA DA COSTA CHIANCA

ORIENTADORA: Danielle Moreira

2010.2

PONTIFÍCIA UNIVERSIDADE CATÓLICA DO RIO DE JANEIRO

RUA MARQUÊS DE SÃO VICENTE, 225 - CEP 22453-900

RIO DE JANEIRO - BRASIL 


\title{
ASPECTOS AMBIENTAIS QUE ENVOLVEM A ATIVIDADE DE EXPLORAÇÃO E PRODUÇÃO DE PETRÓlEO
}

\author{
por \\ MARIA HELENA DA COSTA CHIANCA
}

Monografia apresentada ao Departamento de Direito da Pontifícia Universidade Católica do Rio de Janeiro (PUC-Rio) para a obtenção do Título de Bacharel em Direito.

Orientadora:

Danielle

Moreira 
Petróleo - Esse produto é o sangue da terra: é a alma da indústria moderna; é a eficiência do poder militar; é a soberania; é a dominação. Tê-lo é ter o sésamo abridor de todas as portas. Não tê-lo é ser escravo. (Monteiro Lobato - 1882-1948) 
Dedico este trabalho ao meu pai, a minha mãe e ao meu namorado que acreditaram em mim e no meu potencial, investindo na minha educação, apoiando e me dando forças em todos os momentos difíceis. Pessoas sem as quais não saberia viver e, as quais são a razão da minha vida. 


\section{Agradecimento}

Agradeço primeiro a Deus por me abençoar, proteger-me todos os dias e me dar condições de estudo e formação. Agradeço aos meus pais (Cláudio e Marilena), ao meu namorado (Gabriel), à minha babá (Ilma), aos meus familiares e amigos, por toda paciência e compreensão nos dias em que estava ansiosa e não conseguia dar atenção para ninguém (foram muitos dias); à minha orientadora (Danielle), que tanto se dedicou para me ajudar e fazer com que este trabalho ficasse muito bom; a todos os meus professores, que me transformaram numa advogada, em especial ao meu professor de direito ambiental (Oscar), que fez eu me apaixonar pela matéria; à minha antiga supervisora no estágio (Miriam), que tanto me ensinou sobre a matéria; à todos os advogados que já me supervisionaram (Alexandre, Márcio, Fernando, Álvaro, Cláudia e Ângela), que sempre tiveram a preocupação $\mathrm{n}^{\mathrm{o}} 1$ com o meu aprendizado; aos funcionários do departamento de direito e à equipe do NPJ, que me acompanharam durante esta etapa da minha vida que está prestes a se encerrar, em especial ao Leopoldo, que me ajudou, com toda boa vontade do mundo, a preparar o resultado final deste trabalho. Todas essas pessoas foram essenciais para que o meu aprendizado fosse diferenciado e possibilitaram a realização deste trabalho. 


\section{Resumo}

O presente trabalho observou a legislação, jurisprudência e doutrina brasileira com a finalidade de analisar a temática do direito ambiental ligada à atividade desenvolvida pela indústria petrolífera no Brasil e seus impactos no meio ambiente ecologicamente equilibrado. Com o objetivo de consolidar o entendimento geral e estruturado sobre o tema proposto, no decorrer do trabalho é estudado: (i) o conceito, o histórico e o desenvolvimento da atividade da indústria petrolífera no Brasil, bem como se analisou a legislação vigente sobre o tema e o papel da ANP, IBAMA e Marinha do Brasil dentro do contexto de proteção ambiental; (ii) o sistema de licenciamento ambiental padrão, para depois expor o procedimento específico que envolve a atividade petrolífera; e (iii) por fim, serão expostas as características da responsabilidade civil ambiental, considerando os princípios basilares do direito ambiental, assim como os aspectos mais relevantes do dano gerado ao meio ambiente, e a aplicação de tudo perante a atividade em estudo, com uma análise paralela do desastre ambiental envolvendo a petrolífera BP.

Palavras chave: responsabilidade civil ambiental; direito ambiental; meio ambiente; licenciamento ambiental; atividade de exploração e produção; indústria petrolífera; petróleo; direito do petróleo. 


\section{Sumário}

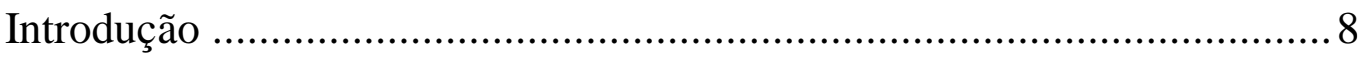

Capítulo 1 - Tratamento legal da atividade de exploração e produção de

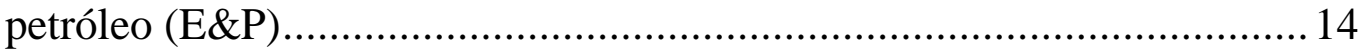

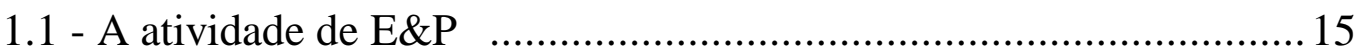

1.2 - Histórico da indústria petrolífera no Brasil ...................................... 16

1.3 - Legislação vigente sobre a temática ...............................................20

1.3.1 - Constituição Federal de 1988 (CF) ............................................20

1.3.2 - Lei Federal n 9.478 (Lei do Petróleo) ……...................................24

1.3.3 - Legislação ambiental sobre o tema …………………….............22

1.4 - O papel da Agência Nacional do Petróleo (ANP), do Instituto Brasileiro do Meio Ambiente e dos Recursos Naturais Renováveis (IBAMA) e da Marinha do Brasil .........................................................32

Capítulo 2 - Licenciamento ambiental pertinente à atividade petrolífera 37

2.1 - Princípios da Prevenção e da Precuação ........................................... 37

2.2 - Avaliação de Impacto Ambiental (AIA)............................................4

2.3 - Breve exposição sobre o licenciamento ambiental ...........................43

2.4 - Tratamento específico concedido para a atividade de E\&P ............48

Capítulo 3 - Responsabilidade civil ambiental na atividade de E\&P ......59

3.1 - Princípio do poluidor pagador (PPP) ………………………........59

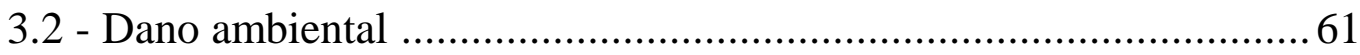

3.3 - Breve exposição sobre a responsabilidade civil ambiental e sua contextualização dentro da atividade de E\&P ........................................66

3.4 - Responsabilidade civil e o contrato de concessão ..............................73 
3.5 - O caso da British Petroleum (BP) e suas consequências 75

Conclusão 79

Referências Bibliográficas 83 


\section{Introdução}

O cenário do mundo atual se encontra marcado por acontecimentos históricos, tais como revolução industrial, globalização e desenvolvimento econômico, os quais trouxeram ao mundo de hoje o paradigma do desenvolvimento desenfreado e predatório. Para Édis Milaré:

Evoluções tecnológicas aceleradas, atitudes agressivas no comércio internacional, a crise financeira global, que eclodiu em fins de 2008 e promete atravessar muitos meses, senão anos, são alguns dos fatores ponderáveis e, simultaneamente, imponderáveis, que nos cerceiam caminhos ou baralham rumos. O avanço do efeito-estufa é inegável, como também o é a crescente perda da biodiversidade. E a depleção de recursos, assim como o cansaço e a exaustão do Planeta, está presente e de má catadura. ${ }^{1}$

Nesta perspectiva, o meio ambiente foi e ainda é muito afetado, porém a conscientização sobre os efeitos adversos das práticas predatórias do nosso mundo globalizado ainda está por se consolidar totalmente. Dentro deste contexto, Paulo Affonso Leme Machado ao falar sobre o princípio do acesso equitativo aos recursos naturais, afirma que:

O homem não é a única preocupação do desenvolvimento sustentável. A preocupação com a natureza deve também integrar o desenvolvimento sustentável. Nem sempre o homem há de ocupar o centro na política ambiental, ainda que comumente ele busque um lugar prioritário. Haverá casos em que para se conservar a vida humana ou para colocar em prática a "harmonia com a natureza" será preciso conservar a vida dos animais e das plantas em áreas declaradas inacessíveis ao próprio homem. ${ }^{2}$

Observa-se que vem ganhando força a proteção do meio ambiente frente às atividades econômicas, passando aquele a ser um limitador das práticas predatórias que só objetivam o lucro e o desenvolvimento desenfreado.

Dentro deste cenário, uma potente fonte de energia ganhou espaço no mundo atual, qual seja, a energia advinda da exploração e produção de petróleo, que, com o passar dos anos, se consolidou como a principal fonte

\footnotetext{
${ }^{1}$ MILARÉ, Édis. Direito do Ambiente. 6 a ed. São Paulo: Revista dos Tribunais, 2009, p. 56.

${ }^{2}$ MACHADO, Paulo Affonso Leme. Direito Ambiental Brasileiro. 17 $7^{\mathrm{a}}$ ed. São Paulo: Malheiros Editores, 2009. p. 63.
} 
energética do atual modelo de desenvolvimento mundial. Porém, a extração e produção desta fonte de energia têm fortes impactos no meio ambiente, hoje protegido constitucionalmente pela nossa Carta da República, como bem de uso comum do povo e essencial à sadia qualidade de vida, sendo um dever de todos garantir a sua proteção (art. 225 da Constituição Federal ${ }^{3}$ ).

Sendo assim, a proteção do meio ambiente passou a ser o limite para a exploração econômica abusiva, colocando um "freio" nas atividades predatórias que só visam ao lucro e não enxergam as consequências futuras, das quais já começamos a sentir seus efeitos na natureza.

Conforme afirma Cristiane Derani, o direito ambiental e o direito econômico são indissociáveis, Vejamos:

O fator natureza, ao lado do fator trabalho e do fator capital, compõe a tríade fundamental para o desenvolvimento da atividade econômica. Isso seria o bastante para explicar a indissociabilidade entre direito econômico e direito ambiental. Contudo, existe um outro ponto, tão ou mais forte que este: a finalidade do direito ambiental coincide com a finalidade do direito econômico. Ambos propugnam pelo aumento do bem-estar ou qualidade de vida individual ou coletiva. ${ }^{4}$

Nota-se que o meio ambiente é necessário para a composição das práticas econômicas e estas são necessárias para levar a sociedade ao bem estar e, assim, proporcionar um meio ambiente que garante a sadia qualidade de vida. Logo, tanto o direito ambiental como o direito econômico são necessários um ao outro e devem interagir para que sempre estejam em sintonia.

Diante deste conjunto de fatos e conseqüências, é importante delinear os aspectos ambientais das atividades da indústria do petróleo (exploração e produção de petróleo), em especial os aspectos do

\footnotetext{
${ }^{3}$ Art. 225 da Constituição Federal de 1988: "Todos têm direito ao meio ambiente ecologicamente equilibrado, bem de uso comum do povo e essencial à sadia qualidade de vida, impondo-se ao Poder Público e à coletividade o dever de defendê-lo e preservá-lo para as presentes e futuras gerações".
} 
licenciamento ambiental e da responsabilidade civil ambiental, inseridos nesta atividade.

Igual contexto de consolidação se encontra a efetivação da legislação ambiental brasileira, que possui sua primeira norma federal datada de 31 de agosto de 1981, com a Lei Federal nº 6.938 (que dispõe sobre a Política Nacional do Meio Ambiente, seus fins e mecanismos de formulação e aplicação), o que pode se considerar recente, levando em conta o tempo que uma legislação leva para amadurecer no ordenamento jurídico e ser posta em prática. Desta forma, encontra-se presente hoje no Brasil um cenário de forte atuação legislativa em face da matéria ambiental. Porém este conjunto de legislação ainda encontra dificuldades com relação à sua eficácia e, aos poucos, os órgãos ambientais, assim como o Ministério Público, estão modificando esta realidade.

Quanto à legislação ambiental envolvendo o setor petrolífero, podemos dizer que esta sim é bem recente, posterior à Emenda Constitucional $n^{\circ}$ 09/95, que abriu o mercado petrolífero brasileiro. Logo, esse contexto envolvendo os aspectos ambientais da atividade de exploração e produção no Brasil, ainda é muito novo, sendo importante um estudo mais aprofundado da matéria.

Recentemente, o mundo inteiro viu a fragilidade desse sistema ao se deparar com o acidente ambiental envolvendo a empresa British Petroleum (BP), que derramou cerca de 5 milhões de barris de petróleo no mar, mais precisamente, no Golfo México, provocando um desastre ambiental irreparável a toda sociedade mundial, afetando a flora e fauna não só local.

Viu-se, também, a dificuldade para sanar e interromper a contaminação, o que nos mostra o quanto o meio ambiente ainda está

\footnotetext{
${ }^{4}$ DERANE, Cristiane. Direito Ambiental Econômico. $3^{\mathrm{a}}$ ed, São Paulo: Saraiva, 2008. p. XXI.
} 
vulnerável diante desta atividade, bem como que as empresas não estão preparadas para conter um desastre ambiental advindo da indústria petrolífera. Deste modo, as consequências do citado desastre, cuja dimensão não tem como ser delineada com precisão, não podem ser desconsideradas.

Tudo isto nos leva a ter certeza que os aspectos ambientais devem ser sempre observados e que este é um campo de tamanha importância, merecendo ser respeitado e muito bem fiscalizado pelas autoridades competentes. Neste contexto se encontra o trabalho da Agência Nacional do Petróleo e Gás (ANP), Instituto Brasileiro do Meio Ambiente e dos Recursos Naturais Renováveis (IBAMA), órgãos ambientais estaduais e municipais e, Marinha do Brasil. Por sua vez, é o licenciamento ambiental um meio de prevenção dos danos contra o meio ambiente e a responsabilização destes atos lesivos, um meio de coerção e imposição de práticas mais seguras e conscientes de exploração e produção.

O presente estudo se embasou numa pesquisa descritiva sobre os aspectos ambientais, concedendo ênfase ao licenciamento ambiental e à responsabilidade civil ambiental, sob o parâmetro das atividades de exploração e produção da indústria petrolífera, utilizando-se dos conceitos da doutrina, do estudo da legislação sobre o tema, do modelo de contrato de concessão e da jurisprudência. Será apresentado ainda, como exemplo, o caso recente de contaminação ambiental envolvendo a empresa British Petroleum (BP) para ilustrar o tema apresentado.

Este trabalho possui como escopo uma abordagem dos aspectos ambientais da atividade de exploração e produção, considerado como o setor de upstream, com enfoque maior para as atividades offshore, ou seja, em que os referidos trabalhos são executados no mar, local onde os danos ambientais são os de maior impacto. Não será objeto deste trabalho as atividades exercidas após a extração do petróleo, a exemplo: o transporte, 
refino, distribuição e revenda do combustível oriundo do petróleo, as quais juntas compõem o setor de downstream.

Visando um entendimento geral e estruturado sobre o tema proposto, no decorrer do trabalho será exposto, no primeiro capítulo, o conceito, o histórico e o desenvolvimento da atividade da indústria petrolífera no Brasil, com a finalidade de contextualizar a temática que está sendo estudada. Neste sentido, também será objeto de estudo a legislação vigente sobre o tema e o trabalho da ANP, IBAMA e Marinha do Brasil dentro do contexto de proteção ambiental.

Considerando o seu papel na matéria ambiental, relevante se faz a presença de um capítulo específico para expor as peculiaridades do licenciamento ambiental de petróleo e gás. Sendo assim, no segundo capítulo se encontra uma breve análise sobre o licenciamento ambiental padrão e o licenciamento ambiental específico da atividade em análise, assim como, sobre a importância da prevenção e precaução em se tratando de matéria ligada aos aspectos naturais.

Paulo Bessa, em livro específico sobre o tema (Proteção Ambiental nas Atividades de Exploração e Produção de Petróleo), explica que a atividade petrolífera está enquadrada dentre as atividades que demandam prévio licenciamento ambiental, uma vez que é considerada potencialmente causadora de impacto ambiental. ${ }^{5}$

No terceiro capítulo serão analisadas as características da responsabilidade civil ambiental, considerando os princípios basilares do direito do ambiente, como o da precaução, prevenção e do poluidor pagador, e os aspectos mais relevantes do dano gerado ao meio ambiente, a aplicação de todos estes instrumentos perante a atividade em estudo, para,

\footnotetext{
5 ANTUNES, Paulo Bessa. Proteção Ambiental nas Atividades de Exploração e Produção de Petróleo: Aspectos Jurídicos. Rio de Janeiro: Lumen Juris, 2003. p. 59.
} 
por fim, ser feita uma análise paralela do desastre ambiental envolvendo a petrolífera BP.

É sobre o cenário relatado acima que o presente trabalho se deterá e buscará uma conclusão. 


\title{
Capítulo 1 - Tratamento legal da atividade de exploração e produção de petróleo (E\&P)
}

\author{
O desenvolvimento econômico é uma realidade inevitável, e mais \\ que isso, uma necessidade que visa ao bem-estar social. Porém o \\ desenvolvimento não está só atrelado à economia, uma evolução deve \\ considerar os aspectos sociais, culturais, políticos e ambientais, além do \\ econômico.
}

O direito ao desenvolvimento é um direito humano inalienável, em virtude do qual toda pessoa e todos os povos estão habilitados a participar do desenvolvimento econômico, social, cultural e político, a ele contribuir e dele desfrutar, no qual todos os direitos humanos e liberdades fundamentais possam ser plenamente realizados. ${ }^{6}$

O meio ambiente não deve ser visto como um obstáculo ao desenvolvimento, mas sim como um aliado deste. Ambos estão intrinsecamente interligados e devem ser tratados conjuntamente, ou seja:

o desenvolvimento não se mantém se a base de recursos ambientais se deteriora; o meio ambiente não pode ser protegido se o crescimento não leva em conta as consequiências da destruição ambiental. Esses problemas não podem ser tratados separadamente por instituições e políticas fragmentadas. Eles fazem parte de um sistema complexo de causa e efeito. ${ }^{7}$

Este é o cerne do princípio do desenvolvimento sustentável. Conforme esclarece Paulo Affonso, a defesa do meio ambiente, à luz do art. 170, VI, da Constituição Federal, faz parte do desenvolvimento nacional. A constituição não estabelece somente o desenvolvimento econômico, mas, também, o desenvolvimento ambiental, econômico e social. A integração destes desenvolvimentos é o que se chama de desenvolvimento sustentável. $^{8}$

\footnotetext{
${ }^{6}$ Art. $1^{\circ}, \S 1^{\circ}$, Declaração sobre o Direito ao Desenvolvimento, a qual foi adotada pela Resolução no 41/128 da Assembléia Geral das Nações Unidas, de 04.12.1986.

${ }^{7}$ Comissão Mundial Sobre Meio Ambiente e Desenvolvimento, Nosso futuro comum, Rio de Janeiro: Fundação Getúlio Vargas, 1988. p.40. Apud: ANTUNES, Paulo Bessa. Direito Ambiental: Amplamente Reformulado. 11ª ed. Rio de Janeiro: Lumen Juris, 2008. p. 24 - 25.

${ }^{8}$ MACHADO, Paulo Affonso Leme. Direito Ambiental Brasileiro. p. 154.
} 
As atividades desenvolvidas pela indústria do petróleo, assim como qualquer outra atividade, não pode deixar de considerar o princípio do desenvolvimento sustentável em suas operações; este "caminha de mãos dadas" com o desenvolvimento econômico.

\section{1 - A atividade de E\&P}

As fontes de energia são umas das grandes preocupações que cercam os países do mundo inteiro, principalmente no que diz respeito ao controle das fontes de que o país necessita para sua subsistência interna. Neste contexto entra o petróleo, como combustível fomentador de energia. ${ }^{9}$ Marilda Rosado destaca, que:

$\mathrm{Na}$ área do petróleo e energia uma constatação preliminar necessária é a da crescente sujeição dos negócios trans-fronteiriços envolvendo a energia a padrões, guias, códigos e princípios, que refletem a globalização e a necessidade de uma regulação pertinente. ${ }^{10}$

Conforme definido pelo inciso XIX, art. $6^{\circ}$, da Lei Federal $n^{\circ}$ 9.478/97, indústria do petróleo é o conjunto de atividades econômicas relacionadas com a exploração, desenvolvimento, produção, refino, processamento, transporte, importação e exportação de petróleo, gás natural e outros hidrocarbonetos fluidos e seus derivados.

A referida lei faz ainda os conceitos de exploração (ou pesquisa), produção (ou lavra) e desenvolvimento, inseridos no mercado de petróleo. Exploração é o conjunto de operações ou atividades destinadas a avaliar áreas, objetivando a descoberta e a identificação de jazidas de petróleo ou gás natural; produção é o conjunto de operações coordenadas de extração de petróleo ou gás natural de uma jazida e de preparo para sua movimentação; e desenvolvimento é o conjunto de operações e

\footnotetext{
${ }^{9}$ MELLO, Celso A. Algumas considerações sobre o petróleo e a ordem internacional. In: ROSADO, Marilda (Org.). Estudos e pareceres: direito do petróleo e gás. Rio de Janeiro: Renovar, 2005.
} 
investimentos destinados a viabilizar as atividades de produção de um campo de petróleo e gás. ${ }^{11}$ Sobre a temática, Luiza Bezerra escreveu:

Quando se fala em indústria do petróleo e gás, deve se ter em mente que se está tratando de uma complexa cadeia de atividades, a qual se inicia na busca pelo petróleo por meio das atividades de exploração, seguindo pela produção, refino, transporte, até a chegada de seus derivados ao consumidor final, por meio da comercialização. Todo esse rol de atividades vê-se subdividido em duas grandes etapas, quais sejam a do upstream, integradas pelas fases de exploração e produção de petróleo, e a do downstream, constituída essencialmente pelas operações de refino, transporte e comercialização de combustíveis e derivados. ${ }^{12}$

Cumpre destacar ainda que a execução das atividades de exploração e produção deverá observar o interesse nacional, o respeito integral ao meio ambiente e ao patrimônio histórico e cultural e a atuação empresarial com responsabilidade social. ${ }^{13}$

\section{2 - Histórico da indústria petrolífera no Brasil}

Na época do império se explorava o petróleo como fluido iluminante, ou seja, o recurso natural era usado para produzir luz, visto que a claridade produzida por este bem era muito mais intensa do que a luz produzida pela chama de uma vela, por exemplo, e esta utilização foi se aprimorando até se chegar à lâmpada de querosene, momento em que a demanda por petróleo se intensificou. ${ }^{14}$ Neste primeiro momento a exploração era considerada sem limites, ou seja, todo mundo poderia explorar petróleo desde que houvesse a permissão do Estado e como contrapartida pagaria uma indenização ao mesmo. ${ }^{15}$

\footnotetext{
${ }^{10}$ RIBEIRO, Marilda Rosado de Sá. O futuro do petróleo - perspectivas jurídicas. Revista do Direito da Energia. São Paulo: Ibde, n. 03, p. 63, 2005.

${ }^{11}$ Art. $6^{\circ}, \mathrm{XV}$, XVI e XVII da Lei Federal n ${ }^{\circ}$ 9.478/97.

12 BEZERRA, Luiza Cavalcanti. O licenciamento ambiental e a desinstalação de operações de petróleo e gás natural no Brasil. Revista do Direito da Energia. São Paulo: Ibde, n. 07, p. 18, 2008.

${ }^{13}$ MELLO, Marcelo de Oliveira. Experiência brasileira nos contratos de produção de petróleo. Revista do Direito da Energia. São Paulo: Ibde, n. 01, p. 41 - 47, 2004.

${ }^{14}$ QUINTAS, Luiz Cezar P.; QUINTAS, Humberto. A História do Petróleo no Brasil e no Mundo. Rio de Janeiro: Freitas Bastos Editora, 2005. p. 21.

${ }^{15}$ Ibid. p. 57.
} 
O sistema consagrado pela Constituição de 1824 era o regaliano. ${ }^{16}$ Segundo Quintas \& Quintas "na época, cada concessão era diretamente solicitada à autoridade imperial, que, discricionariamente, emitia autorização ou negava pedido". ${ }^{17}$

Ainda diante da Constituição de 1824, na década de 1850, o Brasil começava a ver crescer em todas as partes do mundo o mercado de iluminantes e com isso surgiam as primeiras tentativas de extração de petróleo e gás em terras brasileiras. Datam de 1858 as primeiras concessões para extração de petróleo, o que ocorreu na Bahia.

Com a promulgação da Constituição de 1891, consagrou-se o sistema fundiário ou de acessão, em que o Estado "defere ao proprietário do solo, também a propriedade do subsolo". ${ }^{18} \mathrm{Na}$ década de 1930, foi instituído o Código de Minas e por meio do Decreto Lei $n^{\circ} 395 / 38$, o Conselho Nacional do Petróleo, com o fim de elaborar diretrizes e políticas da indústria petrolífera. ${ }^{19}$

Em 1953 o regime mudou por meio da Lei Federal n ${ }^{\circ} 2004$ e a exploração do petróleo passou a ser monopólio do Estado. Concomitantemente foi criada a Petrobrás, empresa estatal que seria responsável pela exploração e produção da atividade no Brasil.

Porém, a exploração exercida pela Petrobrás era muito rudimentar, pois a empresa não possuía experiência técnica na área, o que fez com que durante um tempo a exploração de petróleo no Brasil enfrentasse dificuldades para se desenvolver. ${ }^{20}$ Até que, com a crise mundial da década

\footnotetext{
${ }^{16}$ RIBEIRO, Marilda Rosado de Sá. Direito do petróleo: as joint ventures na indústria do petróleo. 2. ed. Rio de Janeiro: Renovar, 2003, p. 298.

${ }^{17}$ QUINTAS, Luiz Cezar P.; QUINTAS, Humberto. Op. cit., p. 58.

${ }^{18}$ RIBEIRO, Marilda Rosado de Sá. Direito do petróleo: as joint ventures na indústria do petróleo. p. 297.

${ }^{19}$ BEZERRA, Luiza Cavalcanti. Op. cit., p. 15.

${ }^{20}$ QUINTAS, Luiz Cezar P.; QUINTAS, Humberto. Op. cit., p. 74.
} 
de 70, verificou-se a vulnerabilidade da indústria do petróleo nacional, bem como a necessidade de aumentar a nossa produção e criar uma dependência menor do petróleo externo. Com isso, foram instituídos os contratos de risco, em que a Petrobrás permanecia a ter o monopólio da atividade, mas passava a poder contratar outras empresas para exercerem as atividades exploratórias em seu lugar. Marilda Rosado explica este contrato:

O contrato de risco constitui no "ajuste" pelo qual uma empresa internacional de petróleo, ou uma empresa privada brasileira, prestava serviços técnicos operacionais e financeiros à Petrobras, sendo remunerada pelos serviços realizados de acordo com condições preestabelecidas. (...)

Embora seja difícil resumir as linhas mestras do contrato de risco, podem ser ressaltadas as seguintes características: preservação da propriedade da Petrobras sobre o petróleo descoberto, exercício do controle sobre as atividades de exploração e desenvolvimento e a execução direta pela Petrobras da fase de produção. ${ }^{21}$

A Constituição Federal de 1988, porém, vedou estes contratos e retomou o antigo regime de monopólio do exercício da atividade da Petrobras. Até que se começou a questionar o modelo existente e, com a Emenda Constitucional n ${ }^{\circ}$ 09/95, abriu-se o mercado de petróleo no Brasil e a atividade passou a não ser mais uma prerrogativa da Petrobrás (art. 176, $\S 1^{\circ}$ da Constituição Federal). ${ }^{22}$ Foi o fim do monopólio de exploração e produção, porém permaneceu o monopólio de escolha. O petróleo passou a ter a configuração de bem da União (art. 20, IX e $\S 1^{\circ}$ da Constituição Federal $),{ }^{23}$ porém esta podia conceder o exercício da atividade provinda da

\footnotetext{
${ }^{21}$ RIBEIRO, Marilda Rosado de Sá. Direito do petróleo: as joint ventures na indústria do petróleo. p. $302 / 303$.

${ }^{22}$ Art. 176 da Constituição Federal de 1988: "As jazidas, em lavra ou não, e demais recursos minerais e os potenciais de energia hidráulica constituem propriedade distinta da do solo, para efeito de exploração ou aproveitamento, e pertencem à União, garantida ao concessionário a propriedade do produto da lavra.

$\S 1^{\circ} \mathrm{A}$ pesquisa e a lavra de recursos minerais e o aproveitamento dos potenciais a que se refere o "caput" deste artigo somente poderão ser efetuados mediante autorização ou concessão da União, no interesse nacional, por brasileiros ou empresa constituída sob as leis brasileiras e que tenha sua sede e administração no País, na forma da lei, que estabelecerá as condições específicas quando essas atividades se desenvolverem em faixa de fronteira ou terras indígenas".

${ }^{23}$ Art. 20 da Constituição Federal de 1988: "São bens da União: (...)

IX - os recursos minerais, inclusive os do subsolo; (...)
} 
indústria petrolífera a empresas particulares. Veja-se posição de Maria Menezello:

É importante frisar que os bens públicos, aqui representados pelas riquezas minerais, não foram privatizados. O que se pretende privatizar é a exploração da atividade econômica por meio da parceria entre o Estado monopolista e a atividade privada, pagando ao Estado pela participação nessas atividades. ${ }^{24}$

Com a Lei Federal $n^{\circ} 9.478 / 97^{25}$ revogou-se a Lei Federal $n^{\circ}$ 2.004/53 e foram instituídos o Conselho Nacional de Política Energética (CNPE) e a Agência Nacional do Petróleo (ANP), a qual passou ter a competência para estipular as regras e escolher as empresas particulares que poderão exercer a atividade no Brasil, mediante o preenchimento dos requisitos exigidos legalmente e pela Agência.

Podemos concluir, diante do histórico brasileiro, que a atividade passou a ter uma influência significativa no nosso cenário interno faz pouco tempo, logo suas consequências ainda não foram totalmente destacadas e sua regulamentação também é recente, estando todo o contexto ainda em fase de desenvolvimento, assim como o tratamento ambiental dado à atividade. O regramento ambiental brasileiro não é tão recente, porém a legislação ambiental brasileira específica sobre a matéria surgiu no ano de 2000, conforme será explicado no decorrer deste capítulo. Neste sentido discorre Luiza Cavalcante Bezerra:

Diante disso, percebe-se que o novo modelo brasileiro para o setor de exploração e produção de petróleo e gás natural vem incrementando bastante o desenvolvimento dessas atividades no país, numa proporção que gera significativo crescimento à economia, mas que, ao mesmo tempo, exige grandes

$\S 1^{\circ}$ - É assegurada, nos termos da lei, aos Estados, ao Distrito Federal e aos Municípios, bem como a órgãos da administração direta da União, participação no resultado da exploração de petróleo ou gás natural, de recursos hídricos para fins de geração de energia elétrica e de outros recursos minerais no respectivo território, plataforma continental, mar territorial ou zona econômica exclusiva, ou compensação financeira por essa exploração".

${ }^{24}$ MENEZELLO, Maria D’Assunção Costa. Comentários à Lei do Petróleo: Lei Federal n ${ }^{\circ} 9.478$, de 6-8-1997. São Paulo: Atlas, 2000, p. 48.

${ }^{25}$ Denominada Lei do Petróleo, que trata da política energética nacional e das atividades relativas ao monopólio do petróleo. 
cuidados ambientais para que esse se dê em consonância com a sustentabilidade do ambiente e dos recursos naturais. ${ }^{26}$

\section{3- Legislação vigente sobre o tema}

\subsection{1 - Constituição Federal de 1988 (CF):}

O sistema jurídico brasileiro tem a Constituição Federal como lei maior, que deve ser observada e seguida por todas as demais legislações. Desta forma, quando queremos tratar de uma determinada matéria, temos primeiro que verificar o seu tratamento constitucional, para depois analisar a legislação infraconstitucional.

A Constituição Federal de 1988 foi a primeira de nossas constituições a conceder um capítulo específico para o meio ambiente, ${ }^{27}$ demonstrando que o nosso país relaciona o meio ambiente como um bem de uso comum do povo a ser tutelado e respeitado, e mais, o direito ambiental é reconhecido hoje como uma direito fundamental estabelecido pela $\mathrm{CF}^{28}$

$\mathrm{O}$ art. 225, da CF, dispõe claramente que:

todos têm direito ao meio ambiente ecologicamente equilibrado, bem de uso comum do povo e essencial a sadia qualidade de vida, impondo-se ao Poder Público e à coletividade o dever de defendê-lo e preservá-lo para as presentes e futuras gerações.

Note-se que, conforme o preceito constitucional, é dever de todos, ou seja, do Poder Público, assim como da coletividade, o que significa dizer cada um dos seres humanos, individual e socialmente considerados, ${ }^{29}$ defender e preservar o meio ambiente.

Além do capítulo da Constituição dedicado especificamente ao meio ambiente, o legislador constituinte determinou como princípio da ordem

\footnotetext{
${ }^{26}$ BEZERRA, Luiza Cavalcanti. Op. cit., p. 17/18.

27 Art. 225, Capítulo VI, Título VIII - Da Ordem Social, da Constituição Federal de 1988.

${ }^{28}$ MILARÉ, Édis. Op. cit., p. 156.

${ }^{29}$ BENJAMIN, Antônio Herman. Introdução ao Direito Ambiental Brasileiro. Revista de Direito Ambiental. São Paulo:Revista dos Tribunias, v. 14, ano 4, p. 54, abril-junho, 1999.
} 
econômica nacional a proteção do meio ambiente (art. 170, VI da Constituição Federal), ${ }^{30}$ sendo este um dos principais avanços de nossa Constituição de 1988, e de acordo com o mesmo as atividades que violarem o meio ambiente não podem prevalecer, conforme explica Édis Milaré. ${ }^{31}$

Em face do exposto, devemos considerar também o tratamento constitucional da matéria de Direito do Petróleo na CF. Vejamos o que foi escrito por Marilda Rosado:

Todo panorama jurídico nacional aplicável ao petróleo foi alterado pelo que foi disposto na Constituição de 1988, que alçou o monopólio a nível constitucional e proibiu, através do art. 177, inciso I, antes das emendas pertinentes, a celebração de novos contratos de risco, já que o preço dos serviços era vinculado ao resultado de suas descobertas. ${ }^{32}$

Posteriormente, com a promulgação da Emenda Constitucional $\mathrm{n}^{\mathbf{o}}$ 09/95, o monopólio do gás e do petróleo, como já falado, foi "flexibilizado". Com o somatório da publicação da Lei do Petróleo, o setor passou a ser minuciosamente regulado, o que antes era inimaginável aos estudiosos, passando a regular a forma como o Estado atua na economia e na exploração de serviços. ${ }^{33}$

Pois bem, na ordem de disposição dos artigos dentro da CF, temos inicialmente no art. 20, incisos V e IX, a titularidade da União sobre os recursos naturais da plataforma continental e da zona econômica exclusiva; bem como sobre os recursos minerais, inclusive os do subsolo. Sendo assim, o petróleo e o gás natural são bens da União, de propriedade única e

\footnotetext{
${ }^{30}$ Art. 170, da Constituição Federal de 1988: “A ordem econômica, fundada na valorização do trabalho humano e na livre iniciativa, tem por fim assegurar a todos existência digna, conforme os ditames da justiça social, observados os seguintes princípios: (...)

VI - defesa do meio ambiente, inclusive mediante tratamento diferenciado conforme o impacto ambiental dos produtos e serviços e de seus processos de elaboração e prestação".

${ }^{31}$ MILARÉ, Édis. Op. cit., p. 155.

${ }^{32}$ RIBEIRO, Marilda Rosado de Sá. Direito do petróleo: as joint ventures na indústria do petróleo. p. $305-306$.

${ }^{33}$ MENEZELLO, Maria D’Assunção Costa. Op. cit., p. 15.
} 
exclusivamente desta. ${ }^{34}$ Mas vale ressaltar que o $§ 1^{\circ}$ do mesmo artigo dispõe que nos termos da lei é assegurado aos Estados, ao Distrito Federal e aos Municípios, bem como aos órgãos da administração direta da União, participação no resultado da exploração do petróleo ou gás natural.

$\mathrm{O}$ art. 22, IV e XII, da CF determina a competência privativa da União para legislar sobre energia e jazidas, minas e outros recursos minerais. Ainda sobre competência, o art. 23, XI, da CF estabelece a competência comum da União, dos Estados, do Distrito Federal e dos Municípios para registrar, acompanhar e fiscalizar as concessões de direitos de pesquisa e exploração de recursos minerais em seus territórios.

Por fim, o art. 177, inciso I, da CF, dispõe que a pesquisa e lavra das jazidas de petróleo e gás natural e outros hidrocarbonetos fluidos são

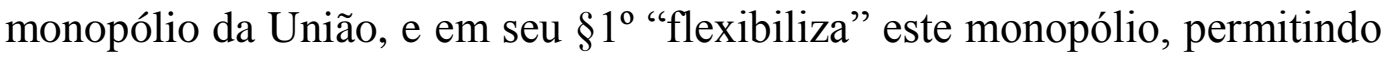
que a União possa contratar com empresas estatais ou privadas a realização destas atividades, observando o disposto em lei (Lei Federal no 9.478/97). Foi em virtude deste $\S 1^{\circ}$ que se passou a dizer que acabou o monopólio exercido na atividade pela Petrobrás, porém permanece o monopólio de escolha da União, neste sentido o Supremo Tribunal Federal (STF) se manifestou na ADI no 3.273. ${ }^{35}$

\footnotetext{
${ }^{34}$ BUCHEB, José Alberto. Direito do petróleo: a regulação das atividades de exploração e produção de petróleo e gás natural no Brasil. Rio de Janeiro: Lumen Juris, 2007, p. 6.

35 EMENTA: CONSTITUCIONAL. MONOPÓLIO. CONCEITO E CLASSIFICAÇÃO. PETRÓLEO, GÁS NATURAL E OUTROS HIDROCARBONETOS FLUÍDOS. BENS DE PROPRIEDADE EXCLUSIVA DA UNIÃO. ART. 20, DA CB/88. MONOPÓLIO DA ATIVIDADE DE EXPLORAÇÃO DO PETRÓLEO, DO GÁS NATURAL E DE OUTROS HIDROCARBONETOS FLUÍDOS. ART. 177, I a IV e $\S \S 1^{\circ}$ E $2^{\circ}$, DA CB/88. REGIME DE MONOPÓLIO ESPECÍFICO EM RELAÇÃ̃O AO ART. 176 DA CONSTITUIÇÃO. DISTINÇÃO ENTRE AS PROPRIEDADES A QUE RESPEITAM OS ARTS. 177 E 176, DA CB/88. PETROBRAS. SUJEIÇÃO AO REGIME JURÍDICO DAS EMPRESAS PRIVADAS [ART. 173, § $1^{\circ}$, II, DA CB/88]. EXPLORAÇÃO DE ATIVIDADE ECONÔMICA EM SENTIDO ESTRITO E PRESTAÇÃO DE SERVIÇO PÚBLICO. ART. $26, \S 3^{\circ}$, DA LEI N. 9.478/97. MATÉRIA DE LEI FEDERAL. ART. 60, CAPUT, DA LEI N. 9.478/97. CONSTITUCIONALIDADE. COMERCIALIZAÇÃO ADMINISTRADA POR AUTARQUIA FEDERAL [ANP]. EXPORTAÇÃO AUTORIZADA SOMENTE SE OBSERVADAS AS POLÍTICAS DO CNPE, APROVADAS PELO PRESIDENTE DA REPÚBLICA [ART. 84, II, $\mathrm{DA} \mathrm{CB} / 88]$.
} 
1. O conceito de monopólio pressupõe apenas um agente apto a desenvolver as atividades econômicas a ele correspondentes. Não se presta a explicitar características da propriedade, que é sempre exclusiva, sendo redundantes e desprovidas de significado as expressões "monopólio da propriedade" ou "monopólio do bem".

2. Os monopólios legais dividem-se em duas espécies: (i) os que visam a impelir o agente econômico ao investimento --- a propriedade industrial, monopólio privado; e (ii) os que instrumentam a atuação do Estado na economia.

3. A Constituição do Brasil enumera atividades que consubstanciam monopólio da União [art. 177] e os bens que são de sua exclusiva propriedade [art. 20].

4. A existência ou o desenvolvimento de uma atividade econômica sem que a propriedade do bem empregado no processo produtivo ou comercial seja concomitantemente detida pelo agente daquela atividade não ofende a Constituição. $O$ conceito de atividade econômica [enquanto atividade empresarial] prescinde da propriedade dos bens de produção.

5. A propriedade não consubstancia uma instituição única, mas o conjunto de várias instituições, relacionadas a diversos tipos de bens e conformadas segundo distintos conjuntos normativos --distintos regimes --- aplicáveis a cada um deles.

6. A distinção entre atividade e propriedade permite que o domínio do resultado da lavra das jazidas de petróleo, de gás natural e de outros hidrocarbonetos fluídos possa ser atribuída a terceiros pela União, sem qualquer ofensa à reserva de monopólio [art. $177 \mathrm{da} \mathrm{CB/88}$ ].

7. A propriedade dos produtos ou serviços da atividade não pode ser tida como abrangida pelo monopólio do desenvolvimento de determinadas atividades econômicas.

8. A propriedade do produto da lavra das jazidas minerais atribuídas ao concessionário pelo preceito do art. 176 da Constituição do Brasil é inerente ao modo de produção capitalista. A propriedade sobre o produto da exploração é plena, desde que exista concessão de lavra regularmente outorgada.

9. Embora o art. 20, IX, da CB/88 estabeleça que os recursos minerais, inclusive os do subsolo, são bens da União, o art. 176 garante ao concessionário da lavra a propriedade do produto de sua exploração.

10. Tanto as atividades previstas no art. 176 quanto as contratações de empresas estatais ou privadas, nos termos do disposto no $\S 1^{\circ}$ do art. 177 da Constituição, seriam materialmente impossíveis se os concessionários e contratados, respectivamente, não pudessem apropriar-se, direta ou indiretamente, do produto da exploração das jazidas.

11. A EC 9/95 permite que a União transfira ao seu contratado os riscos e resultados da atividade e a propriedade do produto da exploração de jazidas de petróleo e de gás natural, observadas as normais legais.

12. Os preceitos veiculados pelos $\S 1^{\circ}$ e $2^{\circ}$ do art. 177 da Constituição do Brasil são específicos em relação ao art. 176, de modo que as empresas estatais ou privadas a que se refere o $\S 1^{\circ}$ não podem ser chamadas de "concessionárias". Trata-se de titulares de um tipo de propriedade diverso daquele do qual são titulares os concessionários das jazidas e recursos minerais a que respeita o art. 176 da Constituição do Brasil.

13. A propriedade de que se cuida, no caso do petróleo e do gás natural, não é plena, mas relativa; sua comercialização é administrada pela União mediante a atuação de uma autarquia, a Agência Nacional do Petróleo - ANP.

14. A Petrobras não é prestadora de serviço público. Não pode ser concebida como delegada da União. Explora atividade econômica em sentido estrito, sujeitando-se ao regime jurídico das empresas privadas [\$ $1^{\circ}$, II, do art. $173 \mathrm{da} \mathrm{CB} / \mathbf{8 8}$ ]. Atua em regime de competição com empresas privadas que se disponham a disputar, no âmbito de procedimentos licitatórios [art. 37, XXI, da CB/88], as contratações previstas no $§ 1^{\circ}$ do art. 177 da Constituição do Brasil.

15. O art. 26, § $3^{\circ}$, da Lei n. 9.478/97, dá regulação ao chamado silêncio da Administração. Matéria infraconstitucional, sem ofensa direta à Constituição.

16. Os preceitos dos arts. 28, I e III; 43, parágrafo único; e 51, parágrafo único, da Lei n. 9.478/98 são próprios às contratações de que se cuida, admitidas expressamente pelo $\S 2^{\circ}$ do art. 177 da CB. 17. A opção pelo tipo de contrato a ser celebrado com as empresas que vierem a atuar no mercado petrolífero não cabe ao Poder Judiciário: este não pode se imiscuir em decisões de caráter político. 
Marilda Rosado também possui este entendimento:

Em linhas gerais afirma-se que o monopólio tornou-se "flexível" porque, embora a propriedade dos recursos do subsolo ainda seja da União Federal, o exercício exclusivo concedido por mais de quarenta anos a uma empresa estatal, a Petrobras, tornou-se aberto a empresas privadas através da celebração de contratos de concessão para as atividades de upstream ou por meio de autorização para as atividades de downstream. ${ }^{36}$

Percebe-se, deste modo, que tanto a matéria ambiental, como a matéria que introduz a exploração e produção do petróleo e gás natural se encontram densamente reguladas pela $\mathrm{CF}$, mostrando a sua importância para a sociedade brasileira.

\subsection{2 - Lei Federal no 9.478/97 (Lei do Petróleo):}

A Lei Federal no 9.478/97, mais conhecida como Lei do Petróleo, dispõe sobre a política energética nacional, as atividades relativas ao monopólio do petróleo, institui o Conselho Nacional de Política Energética (CNPE) e a Agência Nacional do Petróleo, Gás Natural e Biocombustíveis (ANP) e dá outras providências.

Conforme já mencionado, esta lei configurou um marco dentro do Direito, e com a mesma "começa a ser estruturado no sistema jurídico brasileiro um novo ramo do Direito; uma nova especialização, que poderíamos chamar de "Direito Petrolífero". 37 Fruto das mudanças oriundas da Emenda Constitucional $n^{\circ}$ 09/95, a referida lei veio disciplinar o monopólio de escolha introduzido pela mencionada emenda no $\S 1^{\circ}$ do art. 177 da CF, e para tanto criou a ANP e o CNPE.

18. Não há falar-se em inconstitucionalidade do art. 60, caput, da Lei n. 9.478/97. O preceito exige, para a exportação do produto da exploração da atividade petrolífera, seja atendido o disposto no art. $4^{\circ}$ da Lei n. 8.176/91, observadas as políticas aprovadas pelo Presidente da República, propostas pelo Conselho Nacional de Política Energética - CNPE [art. 84, II, da $\mathrm{CB} / 88]$.

19. Ação direta julgada improcedente. (STF, ADI no 3.273, Rel. Ministro Carlos Brito e Ministro Eros Grau, DF, DJ. 16.03.2005.) - (original sem grifos).

${ }^{36}$ RIBEIRO, Marilda Rosado de Sá. Direito do petróleo: as joint ventures na indústria do petróleo. p. 321/322.

37 MENEZELLO, Maria D’Assunção Costa. Op. cit., p. 51. 
Inicialmente, nota-se que mesmo se tratando da lei do Petróleo, a mesma também estipula regras básicas a serem obedecidas na Política Energética Nacional (PNE), sendo assim a lei dispõe em seu art. $1^{\circ}$, sobre os princípios e objetivos da PNE e no inciso IV do dispositivo consta como objetivo da PNE proteger o meio ambiente e promover a conservação de energia. Vale ainda destacar que nos incisos VIII e XII ainda estão previstas outras condutas a serem observadas em prol do meio ambiente, quais sejam, utilizar fontes alternativas de energia, mediante o aproveitamento econômico dos insumos disponíveis e das tecnologias aplicáveis, e incrementar, em bases econômicas, sociais e ambientais, a participação dos biocombustíveis na matriz energética nacional.

Embora a preservação do meio ambiente esteja sendo considerada claramente como um objetivo a ser respeitado, a PNE possui apenas como instrumento regrador $o$ art. $1^{\circ}$ da Lei do Petróleo, o que não parece ser razoável nem efetivo, uma vez que uma política energética deveria prever muito mais do que seus objetivos, mas também formas de perpetuar suas disposições e colocar em práticas os meios de produção de energia mais benéficos para a sociedade, entretanto esta é uma discussão longa, que foge do objetivo deste trabalho e, por este motivo, não será abordada.

Maria Menezello faz uma importante consideração sobre a relação do meio ambiente com a PNE, vejamos:

De modo geral, verifica-se a inter-relação da proteção do meio ambiente e da conservação de energia, uma vez que muitas fontes resultam de recursos naturais que necessitam ter uma exploração adequada. Finalmente, comungamos da opinião de que "no Brasil atual, uma política de eficiência energética, sistêmica, seletiva e sustentável a longo prazo, ainda está a carecer de uma estruturação flexível de planejamento e da dotação de recursos institucionais, tecnoorganizacionais, financeiros e humanos para reduzir a incerteza $e$ a complexidade de seus desafios", 38

\footnotetext{
${ }^{38}$ Ibid. p. 64.
} 
O Art. $2^{\circ}$ da Lei do Petróleo cria o Conselho Nacional de Política Energética (CNPE) e dispõe sobre suas atribuições, dentre as quais encontramos a atribuição de "promover o aproveitamento racional dos recursos energéticos do País, em conformidade com os princípios enumerados no capítulo anterior e com o disposto na legislação aplicável”. Mais uma vez podemos notar que a preservação dos recursos naturais e consequentemente do meio ambiente foi observada na lei.

Encontra-se previsto no art. $5^{\mathbf{o}}$ da lei em epígrafe o regime de concessão e autorização para as atividades da indústria do petróleo. Do art. $7^{\circ}$ ao 20 trata-se da ANP, de suas atribuições, estrutura, receita e acervo, assim como, de seu processos decisório.

Em seguida, começa a regulamentação específica da atividade de exploração e produção, do edital de licitação e da própria licitação e seu julgamento, do contrato de concessão e das participações governamentais. Após, fala-se do refino do petróleo e do processamento do gás natural, do transporte, importação e exportação dos referidos produtos. Por fim, foi criado um capítulo específico para falar sobre a Petrobras, de como passa a ser a sua atividade com a edição da Lei Federal n ${ }^{\circ}$ 9.478/97 e revogação da Lei Federal no 2.004/53.

Na parte específica sobre o contrato de concessão, há previsão expressa, no art. 44, I, da Lei do Petróleo, que através do contrato o concessionário estará obrigado a adotar em todas as suas operações, as medidas necessárias para conservação dos reservatórios e de outros recursos naturais, para a segurança das pessoas e dos equipamentos e para a proteção do meio ambiente.

Vale mencionar ainda que a Lei do Petróleo ora tratada, com o advento do pré-sal, encontra-se em discussão no Congresso Nacional com um projeto de lei que visa a alterar os seus dispositivos no que consiste ao 
regime de contratação das atividades de pesquisa e lavra de hidrocarbonetos de forma diversa do modelo de concessão para o modelo de partilha de produção, ${ }^{39}$ bem como, pretende criar o Fundo Social (FS) que é um instrumento essencial para maximizar os benefícios para o País das receitas oriundas das atividades petrolíferas; ${ }^{40}$ ambas as alterações serão feitas no que tange à área do pré-sal e às áreas estratégicas.

\subsection{3 - Legislação ambiental sobre o tema}

Os princípios possuem um importante trabalho na estruturação de um tema jurídico, eles são responsáveis por dar um sentido lógico, harmônico, racional e coerente ao ordenamento. ${ }^{41}$ Álvaro Mirra afirma ainda que "é dos princípios que se extraem as diretrizes básicas que permitem compreender a forma pela qual a proteção do meio ambiente é vista na sociedade". ${ }^{4}$

Diante da necessidade de promoção do desenvolvimento sustentável, bem como do caráter irreversível de muitos danos ambientais, merecem também destaque na indústria do petróleo os princípios da prevenção, precaução e do poluidor pagador.

Não há um consenso muito bem definido na doutrina sobre o conceito do princípio da precaução, conforme expõe Paulo Bessa, ${ }^{43}$ mas vale destacar o conceito apresentado por Paulo Affonso sobre o referido princípio:

O princípio da precaução aconselha um posicionamento - ação ou omissão quando haja sinais de risco significativo para as pessoas, animais e vegetais, mesmo que estes sinais não estejam perfeitamente demonstrados. O princípio "significa que medidas podem e, algumas vezes, devem ser tomadas

\footnotetext{
${ }^{39}$ Informação retirada da Exposição de Motivos E.M.I. n ${ }^{\circ} 00038$ - MME/MF/MDIC/MP/CCIVIL de 31.08.2009.

${ }^{40}$ Informação retirada da Exposição de Motivos E.M.I. ${ }^{\circ} 119$ - MF/MME/MP/MDIC/CCIVIL de 31.08.2009.

${ }^{41}$ MIRRA, Álvaro Luiz Valery. Princípios Fundamentais do Direito Ambiental. In: Revista de Direito Ambiental. N ${ }^{\circ}$. 2. São Paulo: Revista dos Tribunais, 1996, p. 51.

${ }^{42}$ Ibid. p. 52.

${ }^{43}$ ANTUNES, Paulo Bessa. Direito Ambiental: Amplamente Reformulado. 11 a ed. p. 29.
} 
equitativamente, se ainda não há prova, mas, mais exatamente, suspeita de efeitos perigosos". ${ }^{44}$

Fato é que o princípio da precaução se tornou um dos princípios mais importantes no Direito Ambiental. ${ }^{45}$

O princípio da prevenção é um princípio semelhante ao da precaução, mas ambos não se confundem. Aquele se aplica nos impactos previamente já mensurados, com os quais se estabelece um nexo de causalidade suficiente para delimitar os danos ambientais que poderão resultar da execução de determinada atividade. ${ }^{46}$ e 47

Já o princípio do poluidor pagador (PPP), como explica Paulo Bessa:

parte da constatação de que os recursos ambientais estão escassos e que o seu uso na produção e no consumo acarretam a sua redução e degradação. Ora, se o custo da redução dos recursos naturais não for considerado nos sistema de preços, o mercado não será capaz de refletir a escassez. ${ }^{48}$

O mesmo autor ressalta que o referido princípio busca dirigir o ônus ambiental da atividade para o próprio usuário dos recursos naturais, afastando estes custos econômicos da sociedade. ${ }^{49}$

Cada vez mais o meio ambiente e a sua proteção ganham espaço na sociedade contemporânea e passam a ser princípios e condições basilares para que certas atividades possam funcionar. Executar uma atividade ou fazer uma obra tem que estar em consonância com o meio ambiente, sendo este o preceito fundamental do desenvolvimento sustentável.

\footnotetext{
${ }^{44}$ MACHADO, Paulo Affonso Leme. O Princípio da Precaução e a avaliação de riscos. Revistas dos Tribunais. São Paulo: Revistas dos Tribunais, v. 856, ano96, p. 36, fev. 2007.

${ }^{45}$ No capítulo 2 deste trabalho o referido princípio será melhor desenvolvido.

${ }^{46}$ ANTUNES, Paulo Bessa. Direito Ambiental: Amplamente Reformulado. $11^{\text {a }}$ ed. p. 45.

${ }^{47}$ Este princípio também será aprofundado no capítulo 2 deste trabalho.

${ }^{48}$ Ibid. p. 65/66.

${ }^{49} \mathrm{O}$ princípio será desenvolvido com maior profundidade no capítulo 3 deste estudo.
} 
Marilda Rosado afirma que "O Brasil tem assumido, no plano internacional, uma postura ativa e alinhada com as mais recentes convenções internacionais, diversas já internacionalizadas". ${ }^{50}$ Não só no plano internacional, mas também no nacional. Diversas são as legislações criadas com o fim único de preservar o meio ambiente. Sobre a atividade de E\&P, pode-se destacar como relevantes as normas a seguir apontadas.

No plano internacional o país é signatário e já internalizou três importantes convenções:

1- Convenção Internacional sobre Responsabilidade Civil em Danos Causados por Poluição por Óleo, de 1969, a qual foi internalizada por meio do Decreto $\mathrm{n}^{\mathrm{o}} 79.437 / 77$;

2- Convenção Internacional para Prevenção da Poluição Causada por Navios, concluída em Londres, em 02.11.1973, alterada pelo Protocolo de 1978, concluído em Londres, em 17.02.1978; bem como suas emendas de 1984 e seus anexos opcionais III, IV e V, a qual foi internalizada, junto com suas emendas e anexos, por meio do Decreto no 2.508/98 (Marpol 73/78);

3- Convenção Internacional sobre Preparo, Resposta e Cooperação em Caso de Poluição por Óleo, assinada em Londres, em 30.11.1990, que foi internalizada pelo Decreto ${ }^{\circ}$ 2.870/98.

No âmbito interno, encontram-se diversas normas que regem o tema. Conforme explica o Ministro Antônio Herman Benjamin, podemos identificar três momentos históricos na evolução da legislação brasileira sobre a temática ambiental: $1^{\mathrm{a}}$ fase é a da exploração desregrada ou do laissez-faire ambiental, que durou desde o período colonial até a década de

\footnotetext{
${ }^{50}$ RIBEIRO, Marilda Rosado de Sá. Direito do petróleo: as joint ventures na indústria do petróleo. p. 386 .
} 
60 do século XX, em que a questão jurídico ambiental não existia, mas tão somente iniciativas pontuais do Poder Público visando à conservação (e não a preservação); $2^{\mathrm{a}}$ fase é a fragmentária, que o legislador passa a se preocupar com pontos específicos do meio ambiente, mas ainda não o enxerga como um todo, criando legislações para inibir as atividades exploratórias, mas como o próprio nome da fase explica, neste momento fragmentava-se o objeto meio ambiente em dados recursos naturais; até que chagamos na $3^{a}$ fase, chamada de holística, em que o ambiente passa a ser protegido de maneira integral e passa a ser considerado um bem jurídico. ${ }^{51}$

A Lei Federal no $\mathbf{n}^{\mathbf{6}} \mathbf{9 3 8 / 8 1}$ é considerada como o marco inicial da fase holística, em que hoje nos encontramos. Ele não só instituiu a Política Nacional do Meio Ambiente, bem como incorporou a Avaliação de Impacto Ambiental, a responsabilidade civil objetiva para o dano ambiental (art.14, $\S 1^{\circ}$ da referida lei), e conferiu ao Ministério Público a legitimação para proteger o meio ambiente. ${ }^{52}$ Também se destaca entre os regramentos gerais, a Lei Federal 9.605/98 que trata sobre as sanções penais e administrativas derivadas de condutas e atividades lesivas ao meio ambiente e o Decreto Federal $\mathbf{n}^{\mathbf{0}} \mathbf{6 . 5 1 4 / 0 8}$ que dispõe sobre infrações e sanções administrativas ao meio ambiente.

Não se pode deixar de citar as inúmeras Resoluções CONAMA, em especial, as Resoluções CONAMA n's 23/93 e 350/04, que dispõem sobre o licenciamento ambiental da atividade de E\&P, e a Resolução CONAMA $\mathbf{n}^{\mathbf{0}}$ 398/08, que dispõe sobre o conteúdo mínimo do Plano de Emergência Individual para acidentes de poluição por óleo em águas sob a jurisdição nacional.

\footnotetext{
${ }^{51}$ BENJAMIN, Antônio Herman. Op. cit., p 51 - 52.

${ }^{52}$ Ibid. p. 52.
} 
Destaque especial deve ser feito para a Lei Federal $\mathbf{n}^{\mathbf{0}}$ 9.966/00, que trata da prevenção, controle e físcalização da poluição causada por lançamento de óleo e outras substâncias nocivas ou perigosas em águas sob jurisdição nacional, aplicada em caráter suplementar a Marpol 73/78. Temse ainda, o Decreto Federal $\mathbf{n}^{\mathbf{0}} \mathbf{4 . 1 3 6 / 0 2}$, que dispõe sobre a especificação das sanções aplicáveis às infrações às regras de prevenção, controle e fiscalização previstas na Lei Federal n ${ }^{\circ}$ 9.966/00. Vale frisar que esta norma proíbe a descarga de substâncias perigosas ou nocivas em águas sob jurisdição nacional, conforme a classificação das substâncias. ${ }^{53}$

A referida lei fala ainda sobre os planos de contingência nacional e emergência, este de responsabilidade de cada empreendedor, os quais se deixarem de dispor deste instrumento estarão sujeitos a multa diária que pode variar de $\mathrm{R} \$ 7.000,00$ a $\mathrm{R} \$ 70.000,00 .{ }^{54}$ Já o plano de contingência nacional deve ser elaborado pelo órgão federal do meio ambiente, conforme disposto no parágrafo único do art. $8^{\circ}$ da lei, e será uma integração de todos os planos de emergência setoriais num conjunto de ações e procedimentos que visarão à definição dos recursos humanos, materiais e equipamentos complementares para a prevenção, controle e combate à poluição das águas. Vale citar as palavras de Paulo Bessa sobre esses planos:

\begin{abstract}
A consolidação dos planos de emergência individuais em um único plano de emergência para a área envolvida deve ser realizada pelas entidades exploradas de portos organizados e instalações portuárias, e, também, pelos proprietários ou operadores de plataformas, sob a coordenação do órgão ambiental competente. $\mathrm{O}$ órgão ambiental local deverá, após a consolidação dos planos de emergência, definir os planos de contingências locais ou regionais, em articulação com os órgãos de defesa civil. Todos os planos de contingência locais e regionais serão consolidados pelo órgão federal de meio ambiente, em consonância com o disposto na OPRC/90, estabelecendo o Plano Nacional de Contingência, em articulação com os órgãos de defesa civil. ${ }^{55}$
\end{abstract}

\footnotetext{
${ }^{53}$ Artigos 15, 16 e 17, da lei Federal no 9.966/00.

${ }^{54}$ Art. 14 do Decreto Federal no 4.136/02.

${ }^{55}$ ANTUNES, Paulo Bessa. Direito Ambiental: Amplamente Reformulado. $11^{\mathrm{a}}$ ed. p. 227.
} 
$\mathrm{O}$ acidente envolvendo a petrolífera $\mathrm{BP}$ vem provocando uma série de mudanças nos ordenamentos jurídicos de todos os países. O Brasil também já está sentindo alguns efeitos. Um deles é que a ANP, o IBAMA e a Marinha começaram a elaborar o Plano Nacional de Contingência para conter vazamentos de petróleo em alto-mar, como nos campos do pré-sal, acima mencionado. O que antes nem ouvíamos falar, após o referido acidente passou a ser meta para o Brasil. ${ }^{56}$

Conforme reportagem do jornal Valor Econômico, a Ministra de Meio Ambiente, Isabella Teixeira, informou que as negociações para o Plano Nacional de Contingência estão sendo realizadas e o Plano estaria pronto até setembro de 2010. O referido instrumento conterá estratégia de remediação que inclua Estados e Municípios, com procedimentos de segurança a serem adotados pelo governo. ${ }^{57}$

\section{4 - O papel da Agência Nacional do Petróleo, do Instituto Brasileiro do Meio Ambiente e dos Recursos Naturais Renováveis e da Marinha do Brasil}

Encontramos no sistema jurídico brasileiro a ANP, o IBAMA e a Marinha do Brasil como os principais órgãos fiscalizadores da atividade de E\&P offshore. O art. 27, e seus incisos, da Lei Federal n ${ }^{\circ}$ 9.966/00 define a responsabilidade de cada um dos órgãos mencionados. ${ }^{58}$

\footnotetext{
${ }^{56}$ ORDOÑEZ, Romana, Um plano nacional contra vazamento: Três meses após desastre nos EUA, ANP, Marinha e Ibama elaboram programa de ação para acidentes do pré-sal. $O$ Globo, Rio de Janeiro, p. 19, 26.07.2010.

${ }^{57}$ ENNES, Juliana. Plano de contingência sai até setembro. Valor Econômico, São Paulo, p. B7, 27.07.2010.

58 Art. 27 da Lei Federal no 9.966/00: "São responsáveis pelo cumprimento desta Lei:

I - a autoridade marítima, por intermédio de suas organizações competentes, com as seguintes atribuições:

a) fiscalizar navios, plataformas e suas instalações de apoio, e as cargas embarcadas, de natureza nociva ou perigosa, autuando os infratores na esfera de sua competência; b) levantar dados e informações e apurar responsabilidades sobre os incidentes com navios, plataformas e suas instalações de apoio que tenham provocado danos ambientais; c) encaminhar os dados, informações e resultados de apuração de responsabilidades ao órgão federal de meio ambiente, para avaliação dos danos ambientais e início das medidas judiciais cabíveis; d) comunicar ao órgão
} 
A Marinha é a entidade protetora do mar por sua natureza. Nada mais justo do que o órgão também estar envolvido na proteção deste bem junto com os órgãos ambientais e com a agência responsável pelo controle econômico da atividade.

Com isso, parte dos royalties advindos da atividade de E\&P são destinados a Marinha do Brasil, que deverá aplicá-los nas atividades de patrulha e proteção das plataformas e bacias petrolíferas brasileiras. ${ }^{59}$

regulador da indústria do petróleo irregularidades encontradas durante a fiscalização de navios, plataformas e suas instalações de apoio, quando atinentes à indústria do petróleo;

II - o órgão federal de meio ambiente, com as seguintes atribuições:

a) realizar o controle ambiental e a fiscalização dos portos organizados, das instalações portuárias, das cargas movimentadas, de natureza nociva ou perigosa, e das plataformas e suas instalações de apoio, quanto às exigências previstas no licenciamento ambiental, autuando os infratores na esfera de sua competência; b) avaliar os danos ambientais causados por incidentes nos portos organizados, dutos, instalações portuárias, navios, plataformas e suas instalações de apoio; c) encaminhar à Procuradoria-Geral da República relatório circunstanciado sobre os incidentes causadores de dano ambiental para a propositura das medidas judiciais necessárias; d) comunicar ao órgão regulador da indústria do petróleo irregularidades encontradas durante a fiscalização de navios, plataformas e suas instalações de apoio, quando atinentes à indústria do petróleo;

III - o órgão estadual de meio ambiente com as seguintes competências:

a) realizar o controle ambiental e a fiscalização dos portos organizados, instalações portuárias, estaleiros, navios, plataformas e suas instalações de apoio, avaliar os danos ambientais causados por incidentes ocorridos nessas unidades e elaborar relatório circunstanciado, encaminhando-o ao órgão federal de meio ambiente; b) dar início, na alçada estadual, aos procedimentos judiciais cabíveis a cada caso; c) comunicar ao órgão regulador da indústria do petróleo irregularidades encontradas durante a fiscalização de navios, plataformas e suas instalações de apoio, quando atinentes à indústria do petróleo; d) autuar os infratores na esfera de sua competência;

IV - o órgão municipal de meio ambiente, com as seguintes competências:

a) avaliar os danos ambientais causados por incidentes nas marinas, clubes náuticos e outros locais e instalações similares, e elaborar relatório circunstanciado, encaminhando-o ao órgão estadual de meio ambiente; b) dar início, na alçada municipal, aos procedimentos judiciais cabíveis a cada caso; c) autuar os infratores na esfera de sua competência;

$\mathrm{V}$ - o órgão regulador da indústria do petróleo, com as seguintes competências:

a) fiscalizar diretamente, ou mediante convênio, as plataformas e suas instalações de apoio, os dutos e as instalações portuárias, no que diz respeito às atividades de pesquisa, perfuração, produção, tratamento, armazenamento e movimentação de petróleo e seus derivados e gás natural; b) levantar os dados e informações e apurar responsabilidades sobre incidentes operacionais que, ocorridos em plataformas e suas instalações de apoio, instalações portuárias ou dutos, tenham causado danos ambientais; c) encaminhar os dados, informações e resultados da apuração de responsabilidades ao órgão federal de meio ambiente; d) comunicar à autoridade marítima e ao órgão federal de meio ambiente as irregularidades encontradas durante a fiscalização de instalações portuárias, dutos, plataformas e suas instalações de apoio; e) autuar os infratores na esfera de sua competência".

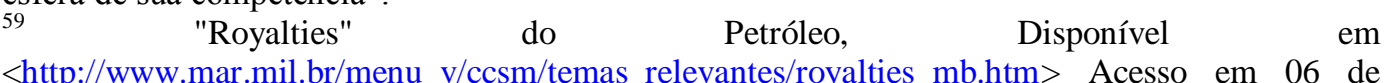
setembro de2010. 
A abertura do mercado de exploração e produção de petróleo foi fruto do processo de desestatização da economia brasileira dos anos 90 . Para que este processo obtivesse êxito - no caso do petróleo com a "flexibilização" do monopólio estatal - foi necessário a criação de organismos com atribuição de regular e fiscalizar os serviços públicos concedidos à iniciativa privada. ${ }^{60}$ Maria Menezello destaca que:

O fundamento de validade desses órgãos é o efetivo exercício do poder de polícia, a fim de assegurar a predominância do interesse público e o atendimento das necessidades dos usuários dos serviços. Dessa forma, realiza-se o controle estatal preventiva ou repressivamente, por meio da regulação e da aplicação de sanções administrativas decorrentes da legislação. ${ }^{61}$

A ANP surgiu neste contexto de reformas constitucionais e legais. Em 1998 foi efetivamente organizada, e em seus anos iniciais empenhou-se no recebimento de dados e informações sobre os assuntos relacionados a upstream e downtrem, que até então eram controlados pela Petrobras. ${ }^{62}$

Dentre suas atribuições, constatamos que a lei concedeu à ANP apenas as funções regulatórias e fiscalizatórias, além da promoção dos certames licitatórios para outorga dos contratos de concessão. Como destacado por Maria Menezello, as questões políticas de planejamento e de fixação de preços continuaram como atribuições do poder executivo, representado pelo CNPE e pelos Ministérios, cabendo à ANP realizar os estudos e pesquisas que possibilitam as decisões políticas. ${ }^{63}$

Vale destacar que, dentre as finalidades da ANP enumeradas pelo art. $8^{\circ}$ da lei, cabe à agência "fazer cumprir as boas práticas de conservação e uso racional do petróleo, gás natural e seus derivados e biocombustíveis e

\footnotetext{
${ }^{60}$ MENEZELLO, Maria D’Assunção Costa. Op. cit., p. 85.

${ }^{61}$ Ibid. p. $85-86$.

${ }^{62}$ RIBEIRO, Marilda Rosado de Sá. Direito do petróleo: as joint ventures na indústria do petróleo. p. 374.

${ }^{63}$ MENEZELLO, Maria D’Assunção Costa. Op. cit., p. 87.
} 
de preservação do meio ambiente". Sobre o trabalho da ANP na esfera jurídica, observa Marilda Rosado:

Na esfera jurídica, destaque-se o trabalho da Procuradoria da ANP enfrentando, de um lado, a disposição para o diálogo de grandes players interessados em uma convergência de abordagens no âmbito do contrato de concessão, e de outro lado, o intenso questionamento das próprias limitações de seu poder de mediação e de decisão, nas áreas de downstream e midstream. ${ }^{64}$

O IBAMA, por sua vez, foi criado pela Lei Federal $n^{\circ} 7.735 / 89$, a partir da fusão de quatro órgãos ambientais existentes na época de sua criação: a Secretaria Especial do Meio Ambiente (SEMA), a Superintendência do Desenvolvimento e da Pesca (SUDEPE), o Instituto Brasileiro de Desenvolvimento Florestal (IBDF) e Superintendência da Borracha (SUDHEVEA). ${ }^{65}$ Vale destacar a explicação de Paulo Bessa:

O IBAMA foi criado sob a forma de autarquia federal de regime especial, dotada de personalidade jurídica de direito público com autonomia administrativa e financeira, vinculada ao Ministério do Meio Ambiente, com a finalidade de assessorá-la na formação e coordenação, bem como executar e fazer executar a política nacional do meio ambiente e da preservação, conservação e uso racional, fiscalização, controle e fomento dos recursos naturais. ${ }^{66}$

$\mathrm{O}$ art. $2^{\circ}$ da Lei Federal $n^{\circ} 7.735 / 89$ enumera as atribuições do IBAMA, quais sejam: (i) exercer o poder de polícia ambiental; (ii) executar ações das políticas nacionais de meio ambiente, referentes às atribuições federais, relativas ao licenciamento ambiental, ao controle da qualidade ambiental, à autorização de uso dos recursos naturais e à fiscalização, monitoramento e controle ambiental, observadas as diretrizes emanadas do Ministério do Meio Ambiente; e (iii) executar as ações supletivas de competência da União, de conformidade com a legislação ambiental vigente.

\footnotetext{
${ }^{64}$ RIBEIRO, Marilda Rosado de Sá. Direito do petróleo: as joint ventures na indústria do petróleo. p. 376.

${ }_{65}^{65}$ MACHADO, Paulo Affonso Leme. Direito Ambiental Brasileiro. p. 175.

${ }^{66}$ ANTUNES, Paulo Bessa. Direito Ambiental-Amplamente Reformulado. 11 ${ }^{a}$ ed. p. 121 - 122.
} 
Como se falará mais à frente, o IBAMA tem um importante papel no licenciamento ambiental das atividades de E\&P offshore. Por meio da Portaria Normativa $\mathrm{n}^{\circ}$ 101/93, o IBAMA criou as licenças específicas para as atividades de exploração e produção de petróleo e gás natural e instituiu os instrumentos a serem utilizados no licenciamento ambiental das atividades, como o Estudo de Viabilidade Ambiental (EVA), ${ }^{67}$ quando ainda não havia regulamentação específica sobre o tema no Brasil.

Porém, como o art. $8^{\circ}$ da Lei Federal $\mathrm{n}^{\circ}$ 6.938/81 concedia a prerrogativa de criar licenças ambientais exclusivamente ao Conselho Nacional do Meio Ambiente (CONAMA), aquela portaria nunca surtiu efeito, mas serviu para ressaltar a necessidade de uma legislação específica sobre o tema, e um ano após a criação desta portaria o CONAMA elaborou a Resolução CONAMA 23/94, já citada. ${ }^{68}$

Note, assim, que a ANP junto com o IBAMA e apoio da Marinha, são os órgãos responsáveis por fiscalizar e controlar a atividade de E\&P, considerando a proporção dos impactos ambientais resultantes da exploração da atividade. Importante é que os três órgãos estejam ligados e atuando juntos, com vistas a aprimorar a fiscalização em cima das empresas que exercem a atividade e inibir ou minimizar os possíveis danos ambientais.

Diante de uma breve visão sobre aspectos relevantes da matéria de direito ambiental e de direito do petróleo, passa-se a tratar do licenciamento ambiental e suas especificidades perante a atividade de E\&P.

\footnotetext{
${ }^{67}$ MACHADO, Paulo Affonso Leme. Direito Ambiental Brasileiro. p. 175 - 176.

${ }^{68}$ FERNANDES DA SILVA, Eduardo. Análise crítica do licenciamento ambiental de pesquisas sísmicas terrestres no Brasil. <http://www.nitsustentabilidade.org/Portals/2/documents/cneg5/anais/T8_0144_0715.pdf >.

Acesso em 11 de outubro de 2010.
} 


\section{Capítulo 2 - Licenciamento ambiental pertinente à atividade petrolífera}

\section{1 - Princípios da Prevenção e da Precaução}

O licenciamento ambiental, como um dos instrumentos essenciais para execução da Política Nacional do Meio Ambiente, ${ }^{69}$ é uma das ferramentas mais importante do Direito Ambiental para a prevenção e fiscalização das atividades potencialmente poluidoras.

Vale inicialmente destacar que o princípio da prevenção (junto com o da precaução) é a base do direito ambiental, uma vez que consiste no fato de que em matéria de meio ambiente é prioritário prever os possíveis danos e evitá-los, adotando medidas que reprimam o dano ambiental, ao invés de deixar que o dano ocorra, para vir a remediá-lo. ${ }^{70}$

Paulo Afonso afirma que a informação organizada e a pesquisa são os pressupostos para que ocorra a prevenção e, com isso divide a aplicação do princípio em cinco itens:

$\left.1^{\circ}\right)$ identificação e inventário das espécies animais e vegetais de uma território, quanto à conservação da natureza e identificação das fontes contaminantes das águas e do mar, quanto ao controle da poluição; $2^{\circ}$ ) identificação e inventário dos ecossistemas, com a elaboração de um mapa ecológico; $3^{\circ}$ ) planejamentos ambiental e econômico integrados; $4^{\circ}$ ) ordenamento territorial ambiental para valorização das áreas de acordo com sua aptidão; e $5^{\circ}$ ) Estudo de Impacto Ambiental. $^{71}$

Destaca-se passagem do livro Direito Ambiental de Paulo Bessa, sobre o princípio da prevenção:

Com base no principio da prevenção o licenciamento ambiental e, até mesmo, os estudos de impacto ambiental podem ser realizados e podem ser solicitados pelas autoridades públicas. Pois, tanto o licenciamento quanto os estudos prévios de impacto ambiental são realizados com base em conhecimentos acumulados sobre meio ambiente. $\mathrm{O}$ licenciamento ambiental, na qualidade de principal instrumento apto a prevenir danos ambientais, age de forma a evitar e, especialmente,

\footnotetext{
${ }^{69}$ Art. $9^{\circ}$, IV da Lei Federal n ${ }^{\text {o }} 6.938 / 81$.

${ }^{70}$ MILARÉ, Édis. Direito do Ambiente. $4^{\mathrm{a}}$ ed. São Paulo: Revista dos Tribunais, 2005, p. 166.

${ }^{71}$ MACHADO, Paulo Affonso Leme. Direito Ambiental Brasileiro. p. 92.
} 
minimizar e mitigar os danos que uma determinada atividade causaria ao meio ambiente, caso não fosse submetida ao licenciamento ambiental. ${ }^{72}$

Além do seu eminente caráter preventivo, o licenciamento ambiental é o meio pelo qual podemos chegar ao desenvolvimento sustentável, impondo ao empreendedor um controle por parte da Administração Pública, sobre a sua atividade, de modo a proporcionar que o desenvolvimento econômico esteja atrelado à proteção do meio ambiente. Podemos depreender este entendimento dos ensinamentos do autor Edis Milaré:

Como ação típica e indelegável do Poder Executivo, o licenciamento constitui importante instrumento de gestão do ambiente, na medida em que, por meio dele, a Administração Pública busca exercer o necessário controle sobre as atividades humanas que interferem nas condições ambientais, de forma a compatibilizar o desenvolvimento econômico com a preservação do equilíbrio ecológico. Isto é, como prática do poder de policia administrativa, não deve ser considerado como obstáculo teimoso ao desenvolvimento, porque este também é um ditame natural e anterior a qualquer legislação. Daí sua qualificação como "instrumento da Política Nacional do Meio Ambiente". ${ }^{73}$

Já sobre o princípio da precaução, conforme expõe Paulo Bessa, este surgiu na década de 70 do século XX, com o Direito alemão, momento em que se notou a necessidade de avaliar previamente os impactos de uma atividade no meio ambiente. ${ }^{74}$ Para Paulo Affonso, "demorou-se muito em prevenir-se a destruição da natureza, e a transformação do mundo natural era feita sem atentar-se para os resultados". 75

Ao analisar o conceito de precaução, pode-se dizer que esta palavra significa cuidado, traz consigo a ação de afastar o possível perigo e segurar as gerações futuras, estando implícita a concepção de sustentabilidade ambiental. $^{76}$ Cristiane Derani afirma que "Precaução ambiental é necessariamente modificação do modo de desenvolvimento da atividade

\footnotetext{
${ }^{72}$ ANTUNES, Paulo Bessa. Direito Ambiental: Amplamente Reformulado. 11 $1^{\mathrm{a}}$ ed. p.45.

${ }^{73}$ MILARÉ, Édis. Direito do Ambiente. $4^{\text {a }}$ ed. p. 534 - 535.

${ }^{74}$ ANTUNES, Paulo Bessa. Direito Ambiental: Amplamente Reformulado. $11^{\text {a }}$ ed. p. 28.

${ }^{75}$ MACHADO, Paulo Affonso Leme. O Princípio da Precaução e o Direito Ambiental. Revista de Direitos Difusos. São Paulo: Adcoas, v.8, p. 1081, 2001.

${ }^{76}$ DERANE, Cristiane. Op. cit., p. 152.
} 
econômica". 77 Vale frisar que para o Direito Ambiental a atividade preventiva (e que age com precaução) é mais valiosa do que as atividades de reparação e repressão. ${ }^{78}$

Paulo Affonso cita trecho do Comunicado da Comissão relativo ao Princípio da Precaução, ocorrido em Bruxelas no dia 02 de fevereiro de 2000, em que se encontra a seguinte explicação:

A invocação do princípio precaução é uma decisão exercida quando a informação científica é insuficiente, não conclusiva ou incerta e haja indicações de que os possíveis efeitos sobre o ambiente, a saúde das pessoas ou dos animais ou a proteção vegetal possam ser potencialmente perigosos e incompatíveis com o nível de proteção escolhido. ${ }^{79}$

Vale ainda destacar os preceitos do princípio ora em comento apresentado por Annelise Steigleder:

O princípio da precaução recomenda ponderação das preocupações ambientais e cautela diante de perigos desconhecidos, mas prováveis, recomendando estudos científicos que busquem a correta dimensão destes perigos a fim de informar os processos decisórios do planejamento ambiental, com vistas à manutenção da poluição em um nível tão baixo quanto possível, a redução dos materiais residuais, a proibição da deterioração significativa do meio ambiente e à triagem de novos produtos. ${ }^{80}$

Porém cumpre ressaltar que o princípio da precaução, assim como o da prevenção, não tem como objetivo imobilizar as atividades humanas, não se trata de impedir todas as atividades humanas, ou ver em cada ação uma propensão para catástrofes ou males, mas o princípio tem sim como

\footnotetext{
${ }^{77}$ Ibid. p. 150.

${ }^{78}$ MILARÉ, Édis. Direito do Ambiente. 6 a ed. p. 955.

79 Comunicado da Comissão relativo ao Princípio da Precaução. Bruxelas, 02.02.2000. COM (2000) 1 final. Apud: MACHADO, Paulo Affonso Leme. O Princípio da Precaução e a avaliação de riscos. Revistas dos Tribunais. São Paulo: Revistas dos Tribunais, v. 856, ano 96, fev. 2007, p. 36. Este Comunicado da Comissão da União Européia possui a finalidade "informar todas as partes interessadas, nomeadamente o Parlamento Europeu, o Conselho e os Estados-Membros, da forma como a Comissão aplica ou pretende vir a aplicar o princípio da precaução quando confrontada com a tomada de decisões referentes à prevenção de riscos" (item 2 do Comunicado). ${ }^{80}$ STEIGLEDER, Annelise Monteiro. Responsabilidade Civil Ambiental: as dimensões do dano ambiental no direito brasileiro. Porto Alegre: Livraria do Edvogado Editora, 2004. p. 188.
} 
finalidade a durabilidade da sadia qualidade de vida e a proteção da natureza existente no planeta. ${ }^{81}$

Em resumo, visa-se por meio do mencionado princípio o afastamento, no tempo e no espaço, do perigo; a proteção do meio ambiente dos possíveis riscos existentes; e uma análise destes riscos e de seu potencial dano.

A sua atuação está presente nas políticas públicas ambientais e em suas criações, com a exigência de uso da melhor tecnologia disponível, formando-se um corolário. ${ }^{82}$ Paulo Bessa ao analisar a Lei Federal $\mathrm{n}^{\mathrm{o}}$ 9.966/00, já mencionada, relaciona o princípio da precaução e a obrigatoriedade inserida pelo art. $9^{\circ}$ da lei de que as instalações portuárias e plataformas realizem auditorias ambientais bienais, independentes, vejamos:

O artigo $9^{\circ}$ da lei que ora se está examinando inovou em nossa legislação, ao estabelecer a obrigatoriedade de que as entidades exploradoras de portos organizados e instalações portuárias e os proprietários ou operadores de plataformas e suas instalações de apoio realizem auditorias ambientais bienais, independentes, com o objetivo de avaliar os sistemas de gestão e controle ambiental em suas unidades. A medida é extremamente salutar e oportuna, pois é somente mediante o exame dos mecanismos de gestão e controle ambiental que, de fato, se pode dar implementação ao princípio da precaução. $^{83}$

Pode-se assim dizer que o princípio da prevenção se aplica quando os impactos ambientais de uma dada atividade já se encontram conhecidos e se possa prever o conjunto de nexos de causalidade mais provável para a mensuração do dano ambiental que decorrerá da ação analisada. ${ }^{84}$ Já no $^{2}$ princípio da precaução não se encontra esta previsibilidade, o agente está

\footnotetext{
${ }^{81}$ MACHADO, Paulo Affonso Leme. O Princípio da Precaução e o Direito Ambiental. p. 1082.

${ }^{82}$ DERANE, Cristiane. Op. cit., p. 151.

83 ANTUNES, Paulo Bessa. Direito Ambiental: Amplamente Reformulado. 11 a ed. p. 227. (original sem grifos)

${ }^{84}$ Ibid. p. 45.
} 
lidando com um risco, do qual não foi possível mensurar o impacto ambiental que possa advir deste.

Diante da essencialidade do meio ambiente ecologicamente equilibrado e constitucionalmente protegido "seguindo a diretriz contida no art. 225, caput e $\$ 3^{\circ}$, da Constituição Federal, reputa-se absolutamente fundamental e indispensável um atuar administrativo rigoroso e permanente na proteção do patrimônio ambiental". ${ }^{85}$

Neste sentido, vale discorrer de maneira breve sobre os principais aspectos do licenciamento ambiental, bem como sobre o tratamento específico dado à atividade exercida pela indústria do petróleo. Ressalta-se que não é objetivo deste trabalho discorrer de maneira extensiva sobre todos os aspectos do licenciamento ambiental, mas sim passar a visão de sua essencialidade para prevenção de possíveis danos que possam ser gerados em virtude da atividade de E\&P.

\section{2 - Avaliação de Impacto Ambiental}

Pressuposto para o licenciamento ambiental é a realização da avaliação de impacto ambiental (AIA), definida como instrumento da Política Nacional de Meio Ambiente. ${ }^{86}$

A AIA é a "actividade administrativa encaminhada para identificar, descrever e estimar os efeitos que a execução de uma determinada obra causa ao ambiente, bem como a adoção das medidas adequadas à sua proteção", ${ }^{87}$ como acentua Colaço Antunes.

\footnotetext{
${ }^{85}$ NETO, Nicolao Dino de C. Costa. Aspectos da tutela preventiva do meio ambiente: avaliação de impacto ambiental e licenciamento ambiental. In: LEITE, José Rubens Morato; BELLO FILHO, Ney de Barros (Org.). Direito Ambiental Contemporâneo. São Paulo: Manole, 2004. p. 179.

${ }_{86}$ Art. $9^{\circ}$, III, da Lei Federal n ${ }^{\circ} 6.938 / 81$.

87 ANTUNES, Luiz Felipe Colaço. O procedimento administrativo de avaliação de impacto ambiental: para uma tutela preventiva do ambiente. Coimbra, Almedina, 1998. p. 191.
} 
Observe que foi com o referido instrumento que se passou a levar em conta o fator ambiental no processo de tomada de decisão ou nas ações que pudessem ou possam vir a ter algum efeito negativo sobre o meio ambiente, configurando o princípio da consideração do meio ambiente na tomada de decisões. ${ }^{88}$ Pode-se concluir que o objetivo da AIA é, assim, a utilização racional e sustentável dos recursos naturais com a observação da proteção do meio ambiente, de forma a prevenir os efeitos adversos em relação ao bem jurídico em tela. ${ }^{89}$

A modalidade mais completa de realização da AIA é o Estudo de Impacto Ambiental (EIA) estabelecido no inciso IV do $\S 1^{\circ}$ do art. 225 da Constituição Federal, assim como nos art. $2^{\circ}$ da Resolução CONAMA $n^{\circ}$ 01/86 e art. $3^{\circ}$ da Resolução CONAMA no 237/90.

O EIA é necessário no licenciamento das atividades potencialmente causadoras de significativa degradação ao meio ambiente. Conforme art. $6^{\circ}$ da Resolução CONAMA nº 01/86, o referido estudo deverá desenvolver um diagnóstico ambiental da área de influência do projeto com completa descrição e análise dos recursos ambientais e suas interações com o meio físico, o meio biológico e o meio socioeconômico; uma análise dos impactos ambientais do projeto e de suas alternativas; a definição das medidas mitigadoras dos impactos negativos; e a elaboração do programa de acompanhamento e monitoramento da atividade e/ou obra. ${ }^{90}$

Além do EIA deve ser elaborado o Relatório de Impacto Ambiental (RIMA), que reflete as conclusões daquele. Ambos são instrumentos distintos, conforme preceitua Paulo Affonso, vejamos:

O Estudo de Impacto Ambiental (EPIA) e o Relatório de Impacto Ambiental (RIMA) apresentam algumas diferenças. O estudo é de maior abrangência que o

\footnotetext{
${ }^{88}$ MILARÉ, Édis. Direito do Ambiente. $6^{\text {a }}$ ed. p. 374.

${ }^{89}$ NETO, Nicolao Dino de C. Costa. Op. cit. p. 180.

${ }^{90}$ Art. $6^{\circ}$, Resolução CONAMA n ${ }^{\circ} 01 / 86$.
} 
relatório e o engloba em si mesmo. O EPIA compreende o levantamento da literatura científica e legal pertinente, trabalhos de campo, análises de laboratório e a própria redação do relatório. Por isso, diz o art. $9^{\circ}$ da Resolução 1/86CONAMA que o "Relatório de Impacto Ambiental-RIMA refletirá as conclusões do Estudo de Impacto Ambiental", ficando patenteado que o EPIA precede o RIMA e é seu alicerce de natureza imprescindível. O relatório transmite - por escrito - as atividades totais do EPIA, importando se acentuar que não se pode criar uma parte transparente das atividades (RIMA) e uma parte não transparente das atividades (EPIA). Dissociado do EPIA, o RIMA perde a validade. ${ }^{91}$

Desta forma, o EIA configura-se como importante instrumento imposto pela Constituição Federal, que deve ser realizado para a instalação de qualquer obra ou atividade potencialmente causadora de significativa degradação do meio ambiente. ${ }^{92}$ e 93

\section{3 - Breve exposição sobre o licenciamento ambiental}

Temos como legislação norteadora para o licenciamento ambiental a Lei Federal no 6.938/81, o Decreto n 99.274/90, a Resolução CONAMA n ${ }^{\circ}$ 237/97 e a Resolução CONAMA nº 01/86, além do disposto no art. 23, VI e no art. $225, \S^{\circ}$, IV da Constituição Federal.

Depreende-se do art. 1º, I da Resolução CONAMA n 237/97 que licenciamento ambiental é:

o procedimento administrativo pelo qual o órgão ambiental competente licencia a localização, instalação, ampliação e a operação de empreendimentos e atividades utilizadoras de recursos ambientais, consideradas efetiva ou potencialmente poluidoras ou daquelas que, sob qualquer forma, possam causar degradação ambiental, considerando as disposições legais e regulamentares e as normas técnicas aplicáveis ao caso.

Segundo Nicolao Dino de C. Costa:

\footnotetext{
${ }^{91}$ MACHADO, Paulo Affonso Leme. Direito Ambiental Brasileiro. p. 231 - 232.

92 ANTUNES, Paulo Bessa. Proteção Ambiental nos Atividades de Exploração e Produção de Petróleo: Aspectos Jurídicos. p. 87.

${ }^{93}$ Neste sentido, destaca-se acórdão do STF sobre o tema: "CONSTITUCIONAL. MEIO AMBIENTE. ESTUDO DE IMPACTO AMBIENTAL - EIA. C.F., ART. 225, §1º IV.

I - Cabe ao Poder Público exigir, na forma da lei, para instalação de obra ou atividade potencialmente causadora de significativa degradação do meio ambiente, estudo prévio de impacto ambiental, a que se dará publicidade. C.F., art. $225, \S 1^{\circ}$, IV.

II - RE provido. Agravo improvido." (STF, Agr. RE n 396541, Rel. Ministro Carlos Velloso, RS, DJ. 05.08.2005.)
} 
O licenciamento ambiental se constitui num procedimento administrativo destinado a produzir um ato-condição para a construção, instalação, ampliação e funcionamento de estabelecimentos e atividade utilizadoras de recursos ambientais, considerados efetiva ou potencialmente poluidores, bem como capazes de, sob qualquer forma, causar degradação ambiental (Lei n. 6.938/81, art. $9^{\circ}$, inc. IV, e art. 10, e Resolução Conama n. 237/97, arts. $1^{\circ}$ e $2^{\circ}$ ). Dele constitui pressuposto a realização de avaliação de impacto ambiental quando se tratar de obra ou atividade causadora de degradação ambiental significativa. ${ }^{94}$

Verifica-se, assim, que o licenciamento ambiental define direitos e obrigações para o exercício da atividade licenciada sendo uma forma de controle exercido pelo ente público destinado à proteção do meio ambiente. $^{95}$

O processo de licenciamento ambiental envolve em geral, três fases, cada qual com uma licença distinta, de acordo com os artigos $8^{\circ}$ e 19 da Resolução CONAMA $n^{\circ} 237 / 87$ e do Decreto $n^{\circ}$ 99.274/90, respectivamente, quais sejam: Licença Prévia (LP), Licença de Instalação (LI) e Licença de Operação (LO). Edis Milaré apresenta a seguinte definição para cada uma dessas licenças:

a) licença prévia: ato pelo qual o administrador atesta a viabilidade ambiental do empreendimento ou atividade e estabelece requisitos básicos e condicionantes a serem atendidos nos próximos passos de sua implementação;

b) licença de instalação: expressa consentimento para o início da implementação do empreendimento ou atividade, de acordo com as especificações constantes dos planos, programas e projetos aprovados;

c) licença de operação: possibilita a operação da atividade ou empreendimento, após a verificação do efetivo cumprimento do que consta nas licenças anteriores. ${ }^{96}$

A LP atesta a viabilidade ambiental do empreendimento ou atividade, e estabelece os requisitos e condicionantes que devem ser atingidos nas próximas fases do licenciamento, para tanto, é necessário a elaboração dos estudos ambientais já mencionados, previamente à emissão

\footnotetext{
${ }_{95}^{94}$ NETO, Nicolao Dino de C. Costa. Op. cit., p. 190.

${ }^{95}$ ANTUNES, Paulo Bessa. Proteção Ambiental nos Atividades de Exploração e Produção de Petróleo: Aspectos Jurídicos. p. 75.

${ }^{96}$ MILARÉ, Édis. Direito do Ambiente. $6{ }^{\mathrm{a}}$ ed. p. 422.
} 
desta licença, levando em consideração o impacto da atividade. ${ }^{97}$ Após, com a emissão da LI está autorizado o início da implantação da obra ou atividade, observando as especificações

Findo o processo de licenciamento ambiental e emitida a LO, o empreendedor está apto para exercer atividade ou executar a obra objeto do licenciamento, porém, cumpre ressaltar, que esta licença não é ad eternum. Uma das características da licença ambiental é justamente a previsão legal ${ }^{98}$ de renovação da mesma. Sendo assim, o art. 18 da Resolução CONAMA no 237/90, estabelece os parâmetros para a concessão dos prazos de validade de cada uma das licenças ambientais citadas de modo a impedir "a perenização de padrões que, sempre, são ultrapassados tecnologicamente". 99

Destaca-se ainda o posicionamento de Paulo Affonso sobre a reparação de danos oriundos de empreendimento ou atividade devidamente licenciada:

A licença ambiental não libera o empreendedor licenciado do seu dever de reparar o dano ambiental. Essa licença, se integralmente regular, retira o caráter de ilicitude administrativa do ato, mas não afasta a responsabilidade civil de reparar. A ausência de ilicitude administrativa irá impedir a própria Administração Pública de sancionar o prejuízo ambiental; mas nem por isso haverá irresponsabilidade civil. ${ }^{100}$

A licença ambiental, não consiste numa "carta de alforria" que permite ao empreendimento ou atividade licenciada poluir o meio ambiente, pelo contrário, na maioria das licenças são estabelecidas condicionantes para que o licenciamento tenha validade.

A Lei Federal n 6.938/81, em seu art. 10, estabeleceu que compete aos órgãos ambientais estaduais o licenciamento ambiental da construção,

\footnotetext{
${ }^{97}$ MACHADO, Paulo Affonso Leme. Direito Ambiental Brasileiro. p. 286.

${ }^{98}$ Art. $9^{\circ}$, IV da Lei Federal n ${ }^{\circ}$ 6.938/81.

99 MILARÉ, Direito do Ambiente. $6^{\text {a }}$ ed. p. 436.

${ }^{100}$ MACHADO, Paulo Affonso Leme. Direito Ambiental Brasileiro. p. 367.
} 
instalação, ampliação e funcionamento de estabelecimentos e atividades utilizadoras de recursos ambientais, considerados efetiva e potencialmente poluidores, bem como os capazes, sob qualquer forma, de causar degradação ambiental, assim como compete ao IBAMA o referido licenciamento em caráter supletivo. No $\S 4^{\circ}$ do mesmo dispositivo, foi feita a exceção de que no caso de atividades e obras com significativo impacto ambiental, de âmbito nacional ou regional a competência para realizar o licenciamento é do IBAMA.

Com a promulgação da Carta da República de 1988, a competência administrativa em questão passou a ser comum a todos os entes da federação, é o que se encontra disposto no art. 23, VI da CF e da mesma forma, no parágrafo único ficou determinado que a cooperação entre os entes federativos nesta matéria deveria ser dada por lei complementar. Com isso, muitos autores, tais como Paulo Affonso, defendem que a lei supracitada não teria sido recepcionada pela Constituição Federal de 1988 neste aspecto, destaca-se trecho da obra doutrinária do referido autor:

\begin{abstract}
A lei federal ordinária não pode retirar dos Estados, do Distrito Federal e dos Municípios poderes que constitucionalmente lhes são atribuídos. (...) e nem a Resolução CONAMA - 237/1997 poderia estabelecer um licenciamento ambiental único. Enquanto não se elaborar essa lei complementar estabelecendo normas para cooperação entre essas pessoas jurídicas, é válido sustentar que todas elas, ao mesmo tempo, têm competência e interesse de intervir nos licenciamentos ambientais. ${ }^{101}$
\end{abstract}

Como citado no trecho acima, a Resolução CONAMA n 237/97 também adentrou nesta matéria, ao estabelecer em seus artigos $4^{\circ}, 5^{\circ}$ e $6^{\circ}$ as competências do IBAMA, órgãos ambientais estaduais e municipais sobre a temática. Porém, sem querer discutir a constitucionalidade das referidas normas infraconstitucionais, na prática o que ocorre é a adoção destas regras. ${ }^{102}$ e 103

\footnotetext{
${ }^{101}$ MACHADO, Paulo Affonso Leme. Direito Ambiental Brasileiro. p. 277.

${ }^{102}$ BEZERRA, Luiza Cavalcanti. Op. cit., p. 24.
} 
Verifica-se também que a lei de crimes ambientais (Lei Federal $n^{\mathbf{o}}$ 9.605/98) estabeleceu, em seu art. 60, que é crime ambiental sujeito a pena de detenção, de um a seis meses, ou multa, ou ambas as penas cumulativamente:

construir, reformar, ampliar, instalar ou fazer funcionar, em qualquer parte do território nacional, estabelecimentos, obras ou serviços potencialmente poluidores, sem licença ou autorização dos órgãos ambientais competentes, ou contrariando as normas legais e regulamentares pertinentes. ${ }^{104}$

Vale ressaltar que não há exceções para o cometimento deste crime, e que o simples fato de não possuir o devido licenciamento ambiental já é suficiente para caracterizar o crime, não sendo necessário que tenha ocorrido um dano ao patrimônio ambiental para configuração do mesmo. ${ }^{105}$

103 A Quinta Turma do TRF $1^{\text {a }}$ Região decidiu sobre a temática ora tratada no mesmo sentido ao aplicar a Lei $\mathrm{n}^{\circ}$ 6.938/81 como fundamentação para sua decisão, veja: "MANDADO DE SEGURANÇA. POSTO REVENDEDOR DE DERIVADOS DE PETRÓLEO. AUTUAÇÃO E INTERDIÇÃ̃O PELO IBAMA POR AUSÊNCIA DE LICENCIAMENTO AMBIENTAL. COMPETÊNCIA SUPLETIVA DO IBAMA. LEIS 6.938/81 E 9.605/98. IRREGULARIDADES. PROVA PRÉ-CONSTITUÍDA. AUSÊNCIA DE DIREITO LÍQUIDO E CERTO.

1. A Lei $n^{0}$ 6.938/81 confere competência supletiva ao IBAMA para fiscalizar as atividades consideradas potencial e efetivamente poluidoras e a Lei $n^{\circ}$ 9.605/98 estabelece sua competência para autuar a instaurar processo administrativo contra condutas lesivas ao meio ambiente.

2. O fato de o pedido de licenciamento ambiental estar em trâmite junto à Secretaria do Meio Ambiente do Distrito Federal - SEMARH não retira a competência do IBAMA para exercer o seu poder de polícia sobre atividades potencialmente poluidoras.

3. A atuação supletiva do IBAMA, apesar de a lei não indicar os seus parâmetros, deverá ocorrer, principalmente, em duas situações: se o órgão estadual ambiental for inepto ou se o órgão permanecer inerte ou omisso.

4. Diante da farta prova produzida pelo IBAMA, não refutada pela recorrente, que não logrou trazer prova pré-constituída capaz de neutralizar a força probante dos laudos produzidos pelo órgão público, dúvida não há quanto à conduta lesiva ao meio ambiente.

5. Apelação improvida." (TRF $1^{\mathrm{a}}$ Região, MS n ${ }^{\mathrm{o}}$ 2003.34.00.000362-8, Rel. Desembargadora Federal Selene Maria de Almeida, DF, Decisão: 13.12.2004). (original sem grifos). (original sem grifos).

${ }_{104}$ Art. 60, Lei Federal no 9.605/98.

${ }^{105}$ Este é o entendimento da Turma Recursal do Tribunal de Justiça do Rio Grande do Sul, se não vejamos: "RECURSO CRIME. DELITOS AMBIENTAIS. ARTIGO 60 DA LEI 9.605/98. EXERCÍCIO DE ATIVIDADE POTENCIALMENTE POLUIDORA. INEXISTÊNCIA DE LICENCIAMENTO AMBIENTAL. SUFICIÊNCIA PROBATÓRIA. SENTENÇA CONDENATÓRIA MANTIDA. Réu que, sem possuir licença ambiental, realiza atividade potencialmente poluidora consistente em criação de suínos sem o devido tratamento de dejetos, pratica o crime ambiental previsto no art. 60 da Lei 9.605/98, que é de mera conduta e que não exige elemento subjetivo do tipo específico. RECURSO DESPROVIDO”. (TJRS, RC $\mathrm{n}^{\circ}$ 71002618288, Rel. Desembargadora Cristina Pereira Gonzales, Porto Alegre, Decisão: 28.06.2010.) (original sem grifos). 
$\mathrm{O}$ art. 60 incrimina a desobediência às normas administrativas e legais ambientais. $^{106}$

Além da ausência do licenciamento para um empreendimento ou atividade, também é crime permanecer a executar a atividade ou obra após a expiração do prazo concedido na licença, sem que tenha ocorrido o necessário pedido de renovação, nesta linha segue a argumentação de Paulo Affonso:

\begin{abstract}
Age com inegável dolo eventual quem (pessoa física ou jurídica) continua operando ou funcionando após a expiração do prazo de validade da licença ou da autorização. Entretanto, deixa de haver dolo direito e/ou eventual quando foi solicitada uma nova licença e/ou autorização no tempo hábil e a pessoa peticionaria está procurando cumprir diligências suplementares determinadas pelo órgão público ambiental. ${ }^{107}$
\end{abstract}

Ressalte-se, que também constitui crime ambiental "obstar ou dificultar a ação fiscalizadora do Poder Público no trato das questões ambientais", ${ }^{108}$ estando sujeito o infrator à pena de detenção, de um a três anos, e multa, conforme disposto no art. 69 da lei de crimes ambientais.

\title{
2.4 - Tratamento específico concedido para a atividade de E\&P
}

Em face desta breve exposição, passa-se a falar sobre o licenciamento ambiental da atividade de E\&P.

Preliminarmente, cumpre informar que o licenciamento da atividade de exploração e produção de petróleo devido à especificidade do tema tratado, não possui igual regramento concedido às demais atividades reguladas pelo licenciamento padrão. O legislador, observando a especificidade e importância do tema, elaborou as Resoluções CONAMA $n^{\text {os }}$ 23/94 e 350/04, sujeitando as atividades envolvidas por E\&P a procedimento próprio de licenciamento, mas também se aplica

\footnotetext{
${ }^{106}$ MACHADO, Paulo Affonso Leme. Direito Ambiental Brasileiro. p. 290.

107 Ibid. p. 289.

108 Art. 69 da Lei Federal n 9.605/98.
} 
subsidiariamente as Resoluções CONAMA nº 01/86 e 237/97, bem como as regras gerais da Lei Federal n ${ }^{\circ}$ 6.938/81, do Decreto $n^{\circ}$ 99.274/90 e, no que couber, as portarias expedidas pela ANP. ${ }^{109}$

A Resolução CONAMA no 23/94 - considerando a necessidade de serem estabelecidos critérios específicos para licenciamento ambiental e objetivando um melhor controle e gestão ambiental das atividades relacionadas à exploração e lavra de jazidas de combustíveis líquidos e gás natural, de acordo com a legislação vigente, ${ }^{110}$ instituiu procedimentos específicos para este licenciamento, porém foi omissa com relação às atividades de aquisição de dados sísmicos marítimos e em zonas de transição, o que levou, após 10 anos de instituição desta, a criação recente da Resolução CONAMA no 350/04.

Vale destacar que para Paulo Bessa aquela Resolução (n 23/94) é falha e não abrange todas as atividades consideradas na indústria do petróleo. Conforme se depreende do art. $2^{\circ}$ do referido regramento legal, a Resolução CONAMA no 23/94 considera atividade de exploração e lavra de jazidas de combustíveis líquidos e gás natural a perfuração de poços para identificação das jazidas e suas extensões; a produção para pesquisa sobre viabilidade econômica; e a produção efetiva para fins comerciais. ${ }^{111}$

Note que, a resolução nada menciona sobre as atividades de sísmica que devem preceder a perfuração de poços para identificação de jazidas mas esta omissão foi suprida pela Resolução CONAMA 350/04, conforme narrado acima - bem como não dispõe sobre o transporte, o refino e a distribuição dos produtos, os quais, segundo Paulo Bessa, são atividades envolvidas por E\&P. Cumpre destacar ainda, trecho do livro do referido

\footnotetext{
${ }^{109}$ MILARÉ, Édis. Direito do Ambiente. $4^{\mathrm{a}}$ ed. p. 570.

${ }^{110}$ Considerandos da Resolução CONAMA no $23 / 94$.

${ }^{111}$ Art. 2 ${ }^{\circ}$, Resolução CONAMA n ${ }^{\circ}$ 23/94.
} 
autor, em que se encontra a clara crítica à Resolução CONAMA nº 23/94, vejamos:

Verifica-se que a legislação brasileira específica sobre o licenciamento ambiental das atividades da indústria do petróleo ainda é inadequada e incapaz de resolver muitas das questões e problemas práticos enfrentados tantos pelos órgãos ambientais competentes como pelos empreendedores. ${ }^{112}$

Fora as críticas, retornando para o teor das Resoluções em análise, no art. $5^{\circ}$ da Resolução CONAMA n ${ }^{\circ}$ 23/94, encontram-se enumeradas as licenças que podem ser concedidas para a atividade de exploração e produção, e no art. $4^{\circ}$ da Resolução CONAMA n ${ }^{\circ}$ 350/04 constam as etapas para o licenciamento ambiental das atividades de aquisição de dados sísmicos marítimos e em zonas de transição.

Seguindo uma ordem cronológica de execução das atividades, primeiro temos os estudos sísmicos para análise da probabilidade de existência de óleo e gás no local objeto da atividade. Para o referido estudo o dispositivo supracitado dispõe que o licenciamento ambiental - o qual é de competência do IBAMA, segundo o parágrafo único do art. $3^{\circ}$ da Resolução CONAMA 350/04 - deverá observar as seguintes etapas: ${ }^{113}$

1. O empreendedor deve encaminhar a Ficha de Caracterização das Atividades (FCA); ${ }^{114}$

2. O IBAMA, então, faz o enquadramento das atividades dentre as seguintes classes:

\footnotetext{
112 ANTUNES, Paulo Bessa. Proteção Ambiental nos Atividades de Exploração e Produção de Petróleo: Aspectos Jurídicos. p. 91 - 92.

${ }_{113}$ Art. $4^{\circ}$ da Resolução CONAMA n ${ }^{\circ} 350 / 04$.

${ }^{114}$ Cumpre explicar que a FCA é um documento sentado pelo empreendedor, em conformidade com o modelo indicado pelo IBAMA, em que são descritos os principais elementos que caracterizam as atividades e sua área de inserção e são fornecidas informações acerca da justificativa da implantação do projeto, seu porte e a tecnologia empregada, os principais aspectos ambientais envolvidos e a existência ou não de estudos e licenças ambientais emitidas por outras instâncias do governo.
} 
a) Classe 1 - Levantamentos em profundidade inferior a 50 metros ou em áreas de sensibilidade ambiental, sujeitos à elaboração de PCAS $^{115}$ e EAS ${ }^{116} /$ RIAS; $^{117}$

b) Classe 2 - Levantamentos em profundidade entre 50 e 200 metros, sujeitos à elaboração de PCAS e EAS/RIAS;

c) Classe 3 - Levantamentos em profundidade superior a 200 metros, sujeitos à elaboração de PCAS;

3. Após, o IBAMA emite o Termo de Referência (TR), ${ }^{118}$ no prazo de 15 dias úteis, contados da data de protocolo da solicitação;

4. Com isso, o empreendedor deve entregar a documentação exigida pelo IBAMA, juntamente com o requerimento da Licença de Pesquisa Sísmica (LPS); ${ }^{119}$

5. Se necessário, o empreendedor deve esclarecer e fornecer informações complementares, caso solicitadas, no prazo máximo de 4 meses, contados do recebimento da respectiva notificação, prazo esse passível de prorrogação, desde que justificado, acordado com o IBAMA e requerido até 30 dias antes de sua expiração;

\footnotetext{
${ }^{115}$ Plano de Controle Ambiental de Sísmica - Documento elaborado pelo empreendedor que prevê as medidas de controle ambiental da atividade de aquisição de dados sísmicos (art. $2^{\circ}, \mathrm{X}$, Resolução CONAMA no 350/04).

${ }^{116}$ Estudo Ambiental de Sísmica - Documento elaborado pelo empreendedor que apresenta a avaliação dos impactos ambientais não significativos da atividade de aquisição de dados sísmicos nos ecossistemas marinho e costeiro (art. $2^{\circ}$, XI, Resolução CONAMA n ${ }^{\circ} 350 / 04$ ).

${ }^{117}$ Relatório de Impacto Ambiental de Sísmica - Documento elaborado pelo empreendedor que apresenta a síntese do EAS em linguagem acessível aos interessados, demonstrando as conseqüências ambientais da implementação das atividades de aquisição de dados sísmicos (art. $2^{\circ}$, XII, Resolução CONAMA no 350/04).

118 TR é um documento fornecido pelo IBAMA ao empreendedor, em que são estabelecidas as diretrizes, o conteúdo mínimo e a abrangência dos estudos ambientais necessários ao licenciamento da atividade de aquisição de dados sísmicos (art. $2^{\circ}, \mathrm{V}$, Resolução CONAMA n ${ }^{\circ}$ 350/04).

${ }^{119}$ Licença de Pesquisa Sísmica é ato administrativo pelo qual o IBAMA autoriza e estabelece condições, restrições e medidas de controle ambiental que devem ser seguidas pelo empreendedor para a realização das atividades de aquisição de dados sísmicos (art. $2^{\circ}$, XIII, Resolução CONAMA n $\left.{ }^{\circ} 350 / 04\right)$.
} 
6. Por fim, o IBAMA de manifesta pelo deferimento ou indeferimento da LPS.

Destaca-se ainda, que o $\S 5^{\circ}$ do art. $4^{\circ}$, em análise, estabelece que "quando a atividade sísmica for considerada pelo IBAMA como potencialmente causadora de significativa degradação ambiental deverá ser exigida, de forma motivada, a apresentação de EIA/RIMA".

Note que conforme a atividade for se afastando da costa terrestre o licenciamento ambiental vai se tornando menos rigoroso, isto porque quanto mais próximo da costa, mais intensos são os impactos ambientais da atividade e um maior cuidado deve ser tomado.

Destacam-se como impactos ambientais da sísmica: (i) para os cetáceos existe o risco na migração das baleias, por exemplo: no Brasil não pode ser executada a atividade em questão quando está no período de migração das baleias-jubarte; (ii) nos peixes, a execução desta atividade provoca dificuldade na percepção sonora, além de assustá-los e deixá-los desorientados; (iii) com relação aos quelônios (exemplo: as tartarugas), se percebe uma evasão, com comportamento errático e diminuição temporária da capacidade auditiva; (iv) já o plâncton sofre uma interferência do recrutamento, mortalidade e danos físicos; $(v)$ e, ainda, a sísmica provoca interferência na atividade pesqueira, provocando danos a petrechos de pesca, restrição de acesso aos pescadores e redução da captura do pescado. ${ }^{120}$

Vale destacar ainda, que ao realizar o referido licenciamento ambiental, o órgão deve observar além dos impactos, as áreas que são mais sensíveis, tais como: bancos de plantas marinhas, estuários e cones de

\footnotetext{
${ }^{120}$ Dados retirados da palestra sobre Licenciamento Ambiental para o setor de Petróleo e Gás, proferida pelo Coordenador do Núcleo de Licenciamento Ambiental (NLA) da Superintendência
} 
dispersão, ambientes recifais (corais e substratos rochosos), áreas de desovas e berçários de peixes, áreas de peca e unidades de conservação; bem como, os períodos sensíveis, a exemplo: defesos e safras de pesca. ${ }^{121}$

Após as atividades de aquisição de dados sísmicos marítimos e em zonas de transição, passamos para o estudo da Resolução CONAMA n ${ }^{\circ}$ 23/94, já mencionada. Observa-se que o licenciamento ambiental específico estabelecido por esta Resolução é elaborado de acordo com a fase em que se encontra a exploração ou produção do petróleo e, sendo assim, possui quatro diferentes tipos de licenças a serem emitidas.

Para cada licença estabelecida, o tratamento legal é diferenciado e é exigida uma AIA distinta, específica para a fase em apreciação de cada caso. No art. $6^{\circ}$ do referido regramento legal encontramos uma descrição dos estudos exigidos. Vejamos, então, quais as licenças ambientais existentes para E\&P e os respectivos estudos ambientais e documentação exigidos.

Licença Prévia para Perfuração (LPper): é a licença que autoriza a atividade de perfuração.

O empreendedor deve apresentar, para a concessão deste ato: a delimitação da área de atuação pretendida; e o Relatório de Controle Ambiental (RCA) das atividades, o qual deve conter a descrição da atividade de perfuração, os riscos ambientais, a identificação dos impactos e as medidas mitigadoras;

\section{Documentação necessária:}

do IBAMA no Rio de Janeiro (SUPES/RJ), Roberto Huet de Salvo Souza, no dia 14 de outubro de 2010, na Pontifícia Universidade Católica do Rio de Janeiro.

121 Dados retirados da palestra sobre Licenciamento Ambiental para o setor de Petróleo e Gás, proferida pelo Coordenador do Núcleo de Licenciamento Ambiental (NLA) da Superintendência do IBAMA no Rio de Janeiro (SUPES/RJ), Roberto Huet de Salvo Souza, no dia 14 de outubro de 2010, na Pontifícia Universidade Católica do Rio de Janeiro. 
1. Requerimento de LPper;

2. RCA;

3. Autorização de desmatamento, quando couber, expedida pelo IBAMA;

4. Cópia da publicação do pedido de LPper.

Cumpre destacar, que se o IBAMA julgar necessário, de forma fundamentada, e em razão da sensibilidade ambiental da área, o órgão ambiental pode aplicar o disposto na Resolução CONAMA n 237/97, art. $3^{\circ}$, e no lugar da LPper e seu respectivo RCA, serão usadas as licenças prévia, de instalação e de operação, como o respectivo EIA/RIMA para a atividade de perfuração. ${ }^{122}$

Cita-se como possíveis impactos ambientais advindos desta atividade: (i) a interferência nas atividades socioeconômicas devido à presença física do navio-sonda e barcos de apoio; (ii) alteração da qualidade da água e sedimento devido ao descarte de efluentes e resíduos; e (iii) eventos acidentais como um vazamento de óleo. ${ }^{123}$

Licença Prévia de Produção para Pesquisa (LPpro): é a licença que autoriza a produção para pesquisa da viabilidade econômica da jazida.

O empreendedor deve apresentar, para a concessão deste ato, o Estudo de Viabilidade Ambiental (EVA), contendo plano de

\footnotetext{
${ }^{122}$ Dados retirados da palestra sobre Licenciamento Ambiental para o setor de Petróleo e Gás, proferida pelo Coordenador do Núcleo de Licenciamento Ambiental (NLA) da Superintendência do IBAMA no Rio de Janeiro (SUPES/RJ), Roberto Huet de Salvo Souza, no dia 14 de outubro de 2010, na Pontifícia Universidade Católica do Rio de Janeiro.

${ }^{123}$ Dados retirados da palestra sobre Licenciamento Ambiental para o setor de Petróleo e Gás, proferida pelo Coordenador do Núcleo de Licenciamento Ambiental (NLA) da Superintendência do IBAMA no Rio de Janeiro (SUPES/RJ), Roberto Huet de Salvo Souza, no dia 14 de outubro de 2010, na Pontifícia Universidade Católica do Rio de Janeiro.
} 
desenvolvimento da produção para a pesquisa pretendida, com avaliação ambiental e indicação das medidas de controle a serem adotadas;

\section{Documentação necessária:}

1. Requerimento de LPpro;

2. EVA;

3. Autorização de desmatamento, quando couber, expedida pelo IBAMA;

4. Cópia da publicação do pedido de LPpro.

Licença de Instalação (LI): é a licença que autoriza, após a aprovação do Estudo de Impacto Ambiental (EIA) ou Relatório de Avaliação Ambiental (RAA), ${ }^{124}$ contemplando ainda outros estudos ambientais existentes na área de interesse, a instalação das unidades e sistemas necessários à produção e ao escoamento da atividade.

O EIA e respectivo RIMA são elaborados de acordo com as diretrizes gerais fixadas pela Resolução CONAMA n 01/86, estes dois instrumentos são usados para novos empreendimentos de produção e escoamento.

O RAA é usado para locais onde já se encontra implantada a atividade e deve conter o diagnóstico ambiental da área, descrição dos novos empreendimentos ou ampliações, identificação e avaliação do impacto ambiental e medidas mitigadoras a serem adotadas, considerando a introdução de outros empreendimentos. Isso porque, quando existem outras

\footnotetext{
${ }^{124}$ Vale esclarecer, que EIA/RIMA é elaborado quando a atividade objeto do licenciamento ainda não foi implementada, e a contrário senso, o RAA é elaborado quando a atividade já se encontra implantada.
} 
atividades implantadas no local, considera-se que já foi elaborado um diagnóstico ambiental da área quando do momento da primeira instalação.

Documentação necessária:

1. Requerimento de LI;

2. RAA ou EIA/RIMA;

3. Outros estudos ambientais pertinentes, se houver;

4. Autorização de desmatamento, quando couber, expedida pelo IBAMA;

5. Cópia da publicação de pedido de LI.

Licença de Operação - LO: é a licença que autoriza o início da operação do empreendimento ou das unidades, instalações e sistemas integrantes da atividade, na área de interesse.

O empreendedor deve apresentar para a concessão deste ato o Projeto de Controle Ambiental - PCA, que deve conter os projetos executivos de minimização dos impactos ambientais avaliados nas fases da LPper, LPpro e LI, com seus respectivos documentos.

Documentação necessária:

1. Requerimento de LO;

2. PCA;

3. Cópia da publicação de pedido de LO.

Para a atividade de produção também encontramos diferentes tipos de impactos ambientais, exemplos: (i) na fase de instalação temos o soterramento de organismos bentônicos, o envolvimento do assoalho 
oceânico e o descarte de "água inibida" (teste de estanqueidade); (ii) na fase de produção temos a água produzida e descartada no mar, derrames de óleo, esgoto sanitário e efluentes, geração de resíduos, emissões atmosféricas e restrição à pesca. ${ }^{125}$

Depreende-se desta explicação, que as licenças LPS e LPper são emitidas na fase de exploração e as licenças LPpro, LI e LO são expedidas já na fase de produção. Diferente do procedimento padrão de licenciamento ambiental disposto na Resolução CONAMA 237/97, as referidas licenças não possuem estipulado legalmente um prazo mínimo e máximo de vigência, este deverá ser concedido discricionariamente pelo órgão ambiental competente pelo licenciamento e findo o seu prazo, a licença poderá ser renovada a pedido do empreendedor. ${ }^{126}$

Quanto à competência para licenciar este tipo de atividade, entendese que para as atividades de E\&P em terra - onshore (o qual, lembre-se, não é o objeto deste trabalho) é do órgão ambiental estadual do lugar do empreendimento e para as atividades de E\&P no mar - offshore a competência é do IBAMA, conforme ensina Edis Milaré:

Portanto as atividades de exploração e produção em terra (onshore) devem ser, em regra, licenciadas pelo órgão ambiental estadual do lugar onde se planeje seu desenvolvimento. (...)

O licenciamento das atividades realizadas no mar (offshore), por sua vez, será de competência originária do IBAMA, na forma do $\S 4^{\circ}$ do art. 10 da mesma Lei, regulamentada pelo at. $19, \S^{\circ}$, do Dec. $99.274 / 90$ e art. $4^{\circ}$ da Resolução CONAMA 237/97. Nesses casos, por razões óbvias, conveniente que o licenciamento seja conduzido por aquele Instituto, através de seu Escritório de Licenciamento das Atividades de Petróleo e Nucleares, sem prejuízo de outras licenças exigíveis. ${ }^{127}$

\footnotetext{
${ }^{125}$ Dados retirados da palestra sobre Licenciamento Ambiental para o setor de Petróleo e Gás, proferida pelo Coordenador do Núcleo de Licenciamento Ambiental (NLA) da Superintendência do IBAMA no Rio de Janeiro (SUPES/RJ), Roberto Huet de Salvo Souza, no dia 14 de outubro de 2010, na Pontifícia Universidade Católica do Rio de Janeiro.

${ }^{126}$ Art. 12 da Resolução CONAMA nº 23/94.

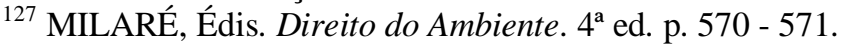


Em suma, o licenciamento ambiental próprio da atividade e E\&P busca conjugar o dinamismo da atividade com a proteção ambiental, de modo a agilizar o processo de licenciamento. ${ }^{128}$ No meu ponto de vista, o fato de existir um tratamento específico para cada etapa da atividade ajuda o órgão ambiental a acompanhar de perto e constantemente a atividade exercida considerando as especificidades (com a devida avaliação de impactos ambiental) de cada fase a ser implementada.

Após uma análise sobre o licenciamento ambiental, passa-se a estudar no próximo capítulo a responsabilidade civil ambiental, considerando os aspectos do impacto ambiental produzido pela atividade desenvolvida pela indústria petrolífera no mar.

${ }^{128}$ Ibid. p. 574. 


\section{Capítulo 3 - Responsabilidade civil ambiental na atividade de E\&P}

\section{1 - Princípio do poluidor pagador (PPP)}

Considerando a relevância dos princípios para a interpretação de um tema jurídico, antes de começar a falar sobre responsabilidade civil ambiental, vale mencionar que os princípios da precaução, da prevenção e do poluidor pagador estão intrinsecamente ligados ao tema. Os dois primeiros princípios já foram abordados no capítulo anterior, mas cumpre fazer uma breve conceituação sobre o PPP.

O mencionado princípio surgiu a partir de 3 constatações distintas: (i) de que as práticas econômicas muitas vezes são utilizadas em detrimento da qualidade ambiental e com isso, acabam por diminuir artificialmente os preços de produtos e serviços; (ii) de que os recursos naturais são escassos; e (iii) de que o custo da redução destes recursos deve ser considerado no sistema de preços praticados no mercado, para que assim seja possível refletir a escassez. ${ }^{129}$

Annelise Steigleder explica que uma das funções da responsabilidade civil é fazer com que o agente causador de danos internalize as externalidades ambientais negativas impondo para as fontes poluidoras "as obrigações de incorporar em seus processos produtivos os custos com prevenção, controle e reparação de impactos ambientais, impedindo a socialização destes riscos". ${ }^{130}$ A autora explica ainda que esta função tem raiz no PPP. O princípio, segundo Édis Milaré:

faz recair sobre o autor do dano o ônus decorrente dos custos sociais de sua atividade. (...) Assume o agente todos os riscos de sua atividade, pondo-se fim,

\footnotetext{
${ }^{129}$ ANTUNES, Paulo Bessa. Direito Ambiental: Amplamente Reformulado. $11^{\mathrm{a}}$ ed. p. 48.

${ }^{130}$ STEIGLEDER, Annelise Monteiro. Op. cit., p. 192.
} 
em tese, à prática inadmissível da socialização do prejuízo e da privatização do lucro. ${ }^{131}$

Ainda sobre o PPP, Paulo Bessa afirma ainda que a sua finalidade é evitar o dano ao meio ambiente ou, não sendo possível, de pelo menos diminuir o impacto ambiental. Para isso o princípio impõe um custo ambiental para os sujeitos econômicos que fazem uso dos recursos naturais para proveito de sua atividade. A idéia básica é de que esses custos não devem ser arcados pela sociedade, visto que a atividade beneficia em específico um dado sujeito econômico. ${ }^{132}$

Maria Alexandra Aragão também estabelece duas finalidades para o PPP: a primeira é a prevenção da poluição e a segunda é a reparação indireta dos danos; ${ }^{133}$ e verifica-se que estas finalidades se encaixam e completam as finalidades apresentadas por Paulo Bessa.

Por fim, cumpre fazer uma observação pertinente sobre o mencionado princípio, a qual é realizada por Cristiane Derani:

As leis que dispõem sobre a internalização dos custos ambientais concentram-se
geralmente até o limite em que não se sobrecarrega o valor dos custos da
produção, evidentemente porque, levando a aplicação do princípio do poluidor
pagador até os seus limites, chegar-se ia à paralisção da dinâmica do mercado,
por uma elevação de preços impossível de ser absorvida nas relações de troca. ${ }^{134}{ }^{2}$

Nota-se que o PPP preceitua a incorporação pelo agente econômico dos custos ambientais produzidos por uma atividade, de modo a inibir os danos ambientais e o repasse destes custos para a sociedade. Porém a aplicação do regramento deve observar o princípio da razoabilidade, considerando que a persecução do PPP não deve acarretar na extinção da

\footnotetext{
${ }^{131}$ MILARÉ, Édis. Direito do Ambiente. 6 a ed. p. 954 - 955.

132 ANTUNES, Paulo Bessa. Dano ambiental: Uma Abordagem Conceitual. Rio de Janeiro: Lumen Juris. 2000. p. 222.

133 ARAGÃO, Maria Alexandra Souza. O princípio do poluidor pagador: pedra angular da política comunitária do meio ambiente. Coimbra: Universidade de Coimbra, Coimbra Editora, 1997. Apud: STEIGLEDER, Annelise Monteiro. Responsabilidade Civil Ambiental: as dimensões do dano ambiental no direito brasileiro. Porto Alegre: Livraria do Edvogado Editora, 2004, p. 193. ${ }^{134}$ DERANE, Cristiane. Op. cit., p. 144.
} 
atividade poluidora. Ou seja, o direito ambiental caminha ao lado do direito econômico, sendo um essencial ao outro.

\section{2 - Dano ambiental}

Pode-se dizer que o cerne do direito ambiental é a proteção do meio ambiente, protegendo-o em especial dos danos que o afetem. A devastação ambiental é um fenômeno que ocorre desde o início dos tempos. O dano ambiental é um dos objetos de maior estudo e preocupação na matéria, tendo em vista as suas consequências para toda coletividade. Neste contexto, os atos lesivos oriundos das atividades petrolíferas estão entre os danos mais complexos, cujo impacto ambiental é de difícil recuperação ou, até, de impossível reparação.

Segundo Moreira Alves, dano consiste em causar prejuízo à coisa alheia, animada ou inanimada. ${ }^{135} \mathrm{O}$ conceito de dano ambiental já é bem mais complicado de ser definido. Veja-se que nem a Constituição Federal, nem qualquer legislação infraconstitucional, se aventurou em apresentar um definição sobre o tema.

$\mathrm{O}$ art. $3^{\circ}$, incisos II e III da Lei Federal $n^{\circ}$ 6.938/81, traz o conceito de degradação ambiental, que não se confunde com o de dano ambiental, mas faz parte deste, e de poluição. Degradação ambiental é a "alteração adversa das características do meio ambiente" ${ }^{136}$, e poluição é a:

degradação da qualidade ambiental resultante de atividades que direta ou indiretamente: a) prejudiquem a saúde, a segurança e o bem-estar da população; b) criem condições adversas às atividades sociais e econômicas; c) afetem desfavoravelmente a biota; d) afetem as condições estéticas ou sanitárias do meio ambiente; e) lancem matérias ou energia em desacordo com os padrões ambientais estabelecidos. ${ }^{137}$

\footnotetext{
${ }^{135}$ MOREIRA ALVES, José Carlos. Direito Romano. $4^{\mathrm{a}}$ ed., Rio de Janeiro: Forense, 1960, p 279. Apud: FREITAS, Vladimir Passos de. A Constituição Federal e a Efetividade das Normas Ambientais. $3^{\text {a }}$ ed. São Paulo: Revista dos Tribunais. 2005, p. 168.

${ }^{136}$ Art. $3^{\circ}$, inciso II da Lei Federal n ${ }^{\circ} 6.938 / 81$.

${ }^{137}$ Art. $3^{\circ}$, inciso III da Lei Federal no ${ }^{\circ} 6.938 / 81$.
} 
Diante destes dois conceitos, Édis Milaré afirma que o legislador vinculou de forma indissociável a poluição e a degradação, uma vez que estabelece que a poluição resulta da degradação, que por sua vez se tipifica no resultado danoso, independentemente da observância das regras impostas ou da atividade estar devidamente autorizada. ${ }^{138}$

Em face da complexidade apresentada, são poucos os doutrinadores que se propõem construir uma definição de dano ambiental. Seguem expostos 3 conceitos encontrados.

Herman Benjamin define dano ambiental como "a alteração, deterioração ou destruição, parcial ou total de quaisquer dos recursos naturais, afetando adversamente o homem e/ou a natureza". ${ }^{139}$

Por sua vez, Édis Milaré apresenta o conceito de dano ambiental como "a lesão aos recursos ambientais, com consequente degradação alteração adversa ou in pejus - do equilíbrio ecológico e da qualidade de vida”. ${ }^{140}$ Por fim, Álvaro Mirra diz que:

O dano ambiental, segundo entendemos, consiste na lesão ao meio ambiente, abrangente dos elementos naturais, artificiais e culturais, como bem de uso comum do povo, juridicamente protegido. Significa, ainda, a violação do direito de todos ao meio ambiente ecologicamente equilibrado, direito humano fundamental, de natureza difusa. ${ }^{141}$

Note que os 3 autores definiram, com palavras distintas, o mesmo conceito para dano ambiental. Em suma, todos alegaram que é uma alteração adversa dos recursos naturais a qual vem a prejudicar o meio ambiente.

\footnotetext{
${ }^{138}$ MILARÉ, Édis. Direito do Ambiente. $6^{\text {a }}$ ed. p. 866.

${ }^{139}$ BENJAMIN, Antônio Herman. Responsabilidade civil pelo dano ambiental. Revista de Direito Ambiental. São Paulo: Revista dos Tribunais, n. 09, p. 48, 1998.

${ }_{140}$ MILARÉ, Édis. Direito do Ambiente. $6^{\mathrm{a}}$ ed. p. 866.

${ }^{141}$ MIRRA, Álvaro Luiz Valery. Ação Civil Pública e a Reparação do Dano ao Meio Ambiente. $2^{\mathrm{a}}$ ed. São Paulo: Editora Juarez de Oliveira, 2004. p. 90.
} 
Para Paulo Bessa, dano ambiental é uma categoria do fenômeno inerente à atividade humana denominado como poluição, o qual se manifesta a partir do consumo de recursos ambientais, e se divide em poluição em sentido estrito (que é desprezível), dano ambiental e crime ambiental. Dano ambiental seria a categoria mais generalizada, "pois incide sobre todos os diferentes elementos que compõem o meio ambiente". ${ }^{142}$

Vale ainda mencionar as características do dano ambiental, segundo Édis Milaré:

$1^{\mathrm{a}}$ - a ampla dispersão de vítimas - o fato danoso, mesmo quando atinge individualmente uma pessoa, irá sempre afetar uma pluralidade difusa de vítimas, tendo em vista a sua definição constitucional como bem de uso comum do povo;

$2^{\mathrm{a}}$ - a dificuldade inerente à ação reparatória - o dano ambiental é de difícil reparação, como já falado, e esta jamais reconstituirá a integridade ambiental ou a qualidade do meio ambiente antes existente; e

$3^{\mathrm{a}}$ - a dificuldade de valoração do dano - a valoração do dano é algo quase impossível, tendo em vista que não existe uma quantificação certa para cada recurso natural, além da dificuldade existente para se verificar a extensão das sequelas deixadas no ambiente. ${ }^{143}$

Tais características acabam por orientar o tratamento que o ordenamento jurídico confere ao dano ambiental.

Diante da complexidade narrada, a reparação natural do meio ambiente $^{144}$ muitas vezes não se torna viável, e diante desta situação tem-se

\footnotetext{
${ }^{142}$ ANTUNES, Paulo Bessa. Dano ambiental: Uma Abordagem Conceitual. p. 244.

143 MILARÉ, Édis. Direito do Ambiente. $6^{\mathrm{a}}$ ed. p. 870 - 871.

144 Ocorre quando cessa a atividade lesiva e repõe o ambiente natural ao status existente antes do dano, em que visa a recuperação, In situ, dos bens afetados. (MILARÉ, Édis. Direito do Ambiente. $6^{\mathrm{a}}$ ed. p. 873.)
} 
uma segunda alternativa para a reparação que ocorre através da compensação, ${ }^{145}$ porém esta também pode não ser factível levando ao agente causador do estrago a arcar com uma indenização em dinheiro, que pode ser considerada como reparação econômica.

Importante frisar que a reparação do prejuízo ambiental deve seguir a ordem acima exposta, ou seja, primeiro deve-se tentar realizar a reparação in natura, não sendo possível, deve-se proceder com a compensação, e se esta também não for viável, o agente causador deverá arcar com uma reparação econômica. Conforme observa Édis Milaré, em todas as hipóteses:

busca o legislador a imposição de um custo ao poluidor, como o que se cumprem, a um só tempo, dois objetivos principais: dar uma resposta econômica aos danos sofridos pela vítima (o indivíduo e a sociedade) e dissuadir comportamentos semelhantes do poluidor ou de terceiros. A efetividade de um e de outro depende, diretamente, da certeza (inevitabilidade) e da tempestividade (rapidez) da ação reparatória. ${ }^{146}$

A poluição dos oceanos, oriunda do derramamento de óleo, é uma das degradações ambientais mais complexas, o desastre ambiental recente envolvendo o derramamento de cerca de 5 milhões de barris de petróleo ${ }^{147}$ pela petrolífera British Petroleum (BP) vem provar esta afirmação. Sobre os impactos provocados pela atividade, cita-se trecho escrito por Álvaro Mirra:

\begin{abstract}
Além do evidente impacto ecológico e para as comunidades costeiras que os vazamentos de petróleo causam, sabe-se que finas camadas de óleo podem concentrar poluentes residuais, como metais pesados, DDT e aminoácidos. E são precisamente esses poluentes crônicos de baixa concentração, e não o óleo em si mesmo, os capazes de acarretar os piores efeitos em termos ecológicos nos regimes dos oceanos, pois tais produtos químicos são persistentes e tendem a acumular-se nas profundidades oceânicas. Apesar do pouco conhecimento científico que se tem sobre o assunto, já se pode concluir que a permanência demorada dessas substâncias nas águas evidencia que os organismos marinhos
\end{abstract}

\footnotetext{
${ }^{145}$ Com a compensação "o objetivo é a substituição dos bens lesados, por outros funcionalmente equivalentes, ainda que situados em local diferente". (MILARÉ, Édis. Direito do Ambiente. $6^{\mathrm{a}}$ ed. p. 873).

${ }^{146}$ MILARÉ, Édis. Direito do Ambiente. $6^{\text {a }}$ ed. p. 874.

${ }^{147}$ BP culpa parceiras por vazamento de plataforma: Empresa indica falhas de subcontratadas em desastre no Golfo do México. Folha de São Paulo, São Paulo, p. A10, 09.09.2010.
} 
ficam a elas expostos por muito tempo, com prejuízos futuros certos às espécies e ecossistemas local. ${ }^{148}$

Desta forma, o ecossistema existente no local é afetado, a cadeia alimentar também sofre consequências, reduz-se a pesca, as praias tornamse impróprias para banho, com significativos prejuízos para as comunidades litorâneas, principalmente para as que vivem do turismo, dentre outras consequências. 149 "Desse modo, o homem corre o risco de se privar de recursos essenciais e de comprometer alguns dos mecanismos fundamentais da biosfera dos quais depende a conservação da vida sobre a terra”. ${ }^{150}$

O complicado é que o mencionado acidente da BP não foi único. Milhares de pequenos derramamentos são efetuados rotineiramente por navios e plataformas, além de outros desastres deste tipo já terem ocorrido anteriormente. Cita-se, dentre os principais acidentes que já acorreram pelo mundo, os seguintes:

\begin{abstract}
junho/1975, o navio-tanque Showa Maru encalha no estreito de Málaga e despeja 237 mil toneladas de petróleo no mar; março/1978, o navio Amoco Cadiz derrama 230 mil toneladas de petróleo do Reino Unido; março/1989, a mais conhecida ocorrência [antes do caso da BP], o petroleiro Exxon Valdez libera 38 mil toneladas de petróleo no Alaska, com gravíssimos danos ambientais; janeiro/1993, o navio tanque Braer colide com rochas ao norte da Escócia e provoca mancha de petróleo de $40 \mathrm{~km}$; janeiro/1993, o cargueiro Maersk Navigator colide com um navio e provoca uma mancha de petróleo de $56 \mathrm{~km}$ nas costas da Malásia e Indonésia; janeiro/1994, o navio Morris J. Furhman encalha na região de Porto Rico e 27 milhões de litros de petróleo vazam; março/1994, colisão do cargueiro Seki no porto de Fujairah origina o vazamento de 15.900 toneladas de petróleo; fevereiro/1996, o Sea Express choca-se com rochas nas proximidades de Milford Haven, Reino Unido, vazando 40 mil toneladas de óleo. ${ }^{151}$
\end{abstract}

\footnotetext{
${ }^{148}$ MIRRA, Álvaro Luiz Valery. Ação Civil Pública e a Reparação do Dano ao Meio Ambiente. p. 100.

${ }_{149}$ FREITAS, Vladimir Passos de. A Constituição Federal e a Efetividade das Normas Ambientais. $3^{\mathrm{a}}$ ed. São Paulo: Revista dos Tribunais. 2005. p. 183.

${ }^{150}$ DORST, Jean. Antes que a natureza morra. Trad. Rita Buongermino. Coord. Mario Guimarães Ferri. São Paulo: Edgard Blücher, 1973. Apud: FREITAS, Vladimir Passos de. A Constituição Federal e a Efetividade das Normas Ambientais. $3^{\mathrm{a}}$ ed. São Paulo: Revista dos Tribunais. 2005, p. 183.

${ }^{151}$ FREITAS, Vladimir Passos de. Op. cit., p. 183.
} 
Estes são alguns dos muitos casos de agressão ambiental provocada por derramamento de petróleo no mar. Essas agressões ao meio ambiente não podem ficar sem resposta, sendo evidente a importância da responsabilidade civil neste cenário. ${ }^{152}$

Cumpre lembrar, que além do evidente dano ambiental causado por derramamento de óleo, há ainda os impactos ambientais já mencionados no capítulo anterior, peculiares de cada fase da atividade de E\&P, os quais já fazem parte do simples execução da exploração ou produção, sem precisar que haja um acidente para que estes ocorram. Como exemplo, cita-se o impacto da atividade de sísmica marítima na percepção sonora dos peixes, ou na restrição de pesca aos pescadores da região.

\section{3 - Breve exposição sobre a responsabilidade civil ambiental e sua contextualização dentro da atividade de E\&P}

A Responsabilidade Civil Ambiental possui no sistema jurídico brasileiro status constitucional, conforme disposto no $\$ 3^{\circ}$ do art. 225 da CF:

\footnotetext{
${ }^{152}$ Sobre o tema, vale citar dois acórdãos do Tribunal de Justiça do Estado do Rio de Janeiro: "Ementa: Direito Ambiental. Ação Civil Pública. Danos ecológicos. Petrobrás. Vazamento de óleo nas plataformas de exploração da Bacia de Campos. Poluição do litoral de Arraial do Cabo. Prova bastante do nexo causal e dos danos. Responsabilidade objetiva. Lei $6.925 / 81$, art. $14, \S 1^{\circ}$. Indenização. Pedido acolhido em parte. Sentença mantida. Demonstrado que a mancha de óleo que chegou às praias decorrera de vazamentos das plataformas de propriedade da Petrobrás, responde ela pelos danos causados ao meio ambiente. Pode o juiz, orientado pelo princípio da razoabilidade, conforme entendimento pretoriano, reduzir a indenização sugerida pelo perito a valor justo. Recursos desprovidos." (TJ RJ, $13^{\mathrm{a}}$ Câmara Cível, AP n ${ }^{\circ}$ 2005.001.44143, Rel. Nametala Machado Jorge, DJ. 28.06.2006) e "Ementa: PROTECAO DO MEIO AMBIENTE. POLUICAO AMBIENTAL. PETROBRAS. RESPONSABILIDADE OBJETIVA. Apelação cível. Poluição ambiental provocada pela Petrobras. Danos provocados ao ecossistema e aos que vivem da pesca. Indenização postulada por armador de pesca. Cabimento. Responsabilidade objetiva. Art. 14, par. 1., da Lei n. 6938/81. O lamentável desastre ecológico verificado na madrugada do dia 18 de janeiro de 2000, que teria lançado aproximadamente 1 milhão e 300 mil litros de óleo cru nas aguas da Baia de Guanabara, teve origem em uma das tubulações da Refinaria Duque de Caxias (Reduc), provocando graves prejuízos de ordem social e econômica `a população local, devido `a contaminação do espelho d'agua, fauna e manguezais, afetando a pesca, o turismo e o lazer. A responsabilidade do poluidor e' objetiva `a luz do art. 14, par. 1., da Lei n. 6938/81. Diante da existência do dano ambiental, com reflexo no aspecto econômico e social, e a indiscutível responsabilidade do réu no desastre ecológico, impõe-se a condenação pelos prejuízos causados ao autor e a existência do nexo de causalidade entre estes e o acidente ecológico em tela. Recurso conhecido e provido." (TJ RJ, 12 $2^{\mathrm{a}}$ Câmara Cível, AP nº 2002.001.15693, Rel. Francisco de Assis Pessanha, DJ. 10.12.2002).
} 
"As condutas e atividades consideradas lesivas ao meio ambiente sujeitarão os infratores, pessoas físicas ou jurídicas, a sanções penais e administrativas, independente da obrigação de reparar os danos causados".

Antes mesmo da CF prever a responsabilidade civil ambiental, a Lei Federal 6.938/81, em seu art. $14, \S 1^{\circ}$, já estabelecia esta responsabilidade, com isso, pode-se dizer que o citado artigo, foi recepcionado pela CF., vejamos:

Art. 14 - Sem prejuízo das penalidades definidas pela legislação federal, estadual e municipal, o não cumprimento das medidas necessárias à preservação ou correção dos inconvenientes e danos causados pela degradação da qualidade ambiental sujeitará os transgressores: (...)

$\S 1^{\circ}$ Sem obstar a aplicação das penalidades previstas neste artigo, é o poluidor obrigado, independentemente da existência de culpa, a indenizar ou reparar os danos causados ao meio ambiente e a terceiros, afetados por sua atividade. O Ministério Público da União e dos Estados terá legitimidade para propor ação de responsabilidade civil e criminal, por danos causados ao meio ambiente. (original sem grifos)

O instituto pressupõe que tenha ocorrido um prejuízo a terceiro e em função disto decorre o pedido da reparação do dano, que pode vir a acontecer por meio da recomposição do recurso natural lesado ao status quo ante ou ao pagamento de uma indenização. ${ }^{153}$

Heman Benjamin afirma que pode-se identificar 6 razões para a descoberta da responsabilidade civil dentro do Direito Ambiental:

a) a transformação do ambiente de recurso infinito e inesgotável (por isso mesmo res communis) em recurso crítico e escasso, daí valorizado, b) a percepção de que a intervenção solitária do Estado, via comando-e-controle (ou seja, Direito Público), não protegia suficientemente o meio ambiente, c) a compreensão de que, por melhores que sejam a prevenção e a precaução, danos ambientais ocorrerão, na medida em que os "acidentes são normais em qualquer atividade", d) o caráter contraditório da mensagem enviado pelo ordenamento ao mercado, colocando seu exercito sancionatório penal e administrativo em combate, e ao mesmo tempo, isentando o bolso (o "órgão" mais sensível do ser humano) do poluidor, ao afastar a possibilidade de sua responsabilização civil, e) surgimento de novos direitos subjetivos, até constitucionalizados (art. 225, da Constituição brasileira, p. ex.), a exigir submissão das condutas anti-ambientais a duplo

${ }^{153}$ MILARÉ, Édis. Direito do Ambiente. $6^{a}$ ed. p. 951. 
controle, público (centralizado) e privado (descentralizado), f) uma maior sensibilidade do Direito para com a posição da vítima (favor victimae), própria do Welfare State. ${ }^{154}$

Ressalta-se que, com o passar do tempo, jurisprudência, doutrina e legislação notaram que as regras clássicas da responsabilidade civil não eram adequadas para proporcionar uma reparação do dano ambiental, devido, em primeiro lugar, à natureza difusa do meio ambiente, que via de regra atinge uma pluralidade de vítimas. Em segundo lugar, podemos citar, como outro empecilho, a dificuldade da prova da culpa do agente poluidor. Em terceiro lugar, porque naquele regime jurídico admitiam-se as clássicas excludentes de responsabilidade. ${ }^{155}$

Diante destas características que o direito ambiental foi ganhando o seu contorno hoje existente, de responsabilidade baseada na regra da objetividade, a qual se fundamenta na teoria do risco da atividade, que se traduz no fato de que "se alguém introduz na sociedade uma situação de risco ou perigo para terceiros, deve responder pelos danos que a partir desse risco criado resultarem". 156

Já em 1979, antes da estipulação de responsabilidade objetiva imposta pelo art. $14, \S 1^{\circ}$ da Lei Federal no 6.938/81, Sérgio Ferraz já defendia que a responsabilidade subjetiva, em matéria ambiental, deveria ser abandonada. ${ }^{157}$

O mesmo autor definiu quais são as consequências da implantação da responsabilidade objetiva, vejamos: (i) a primeira é a irrelevância da intenção danosa, ou seja, basta que o prejuízo tenha advindo, independente da retenção do agente, para configurar a responsabilidade; (ii) a segunda é a irrelevância da mensuração do subjetivismo, o que significa que também

\footnotetext{
${ }^{154}$ BENJAMIN, Antônio Herman. Responsabilidade civil pelo dano ambiental. p. 8 - 9.

${ }^{155}$ MILARÉ, Édis. Direito do Ambiente. 6 a ed. p. 953.

${ }^{156}$ Ibid. p. 953.
} 
não importa se o dano e a intenção de produzi-lo sejam oriundos de várias pessoas, o que importa é o nexo de causalidade; (iii) a terceira é a inversão do ônus da prova, em que parte-se da presunção de que o agente causou o prejuízo, não precisando provar esse dado, e com isso, o agente que passa ter a função de provar que o nexo de causalidade não decorreu de sua conduta; ${ }^{158}$ (iv) a quarta é a irrelevância da licitude da atividade, ou seja,

${ }^{157}$ FERRAZ, Sérgio. Responsabilidade civil por dano ecológico. In Revista de Direitos Difusos. N. 49/90, p. 37. São Paulo: Revista dos Tribunais, 1979.

${ }^{158}$ O instituto da inversão do ônus da prova, ainda provoca muita discussão e não está completamente aceito no nosso sistema jurídico, porém estamos caminhando neste sentido e como prova disto, cita-se 3 acórdãos do STJ determinando a inversão do ônus da prova:

Ementa: PROCESSUAL CIVIL - COMPETÊNCIA PARA JULGAMENTO DE EXECUÇÃO FISCAL DE MULTA POR DANO AMBIENTAL - INEXISTÊNCIA DE INTERESSE DA UNIÃO - COMPETÊNCIA DA JUSTIÇA ESTADUAL - PRESTAÇÃO JURISDICIONAL OMISSÃO - NÃO-OCORRÊNCIA - PERÍCIA - DANO AMBIENTAL - DIREITO DO SUPOSTO POLUIDOR - PRINCÍPIO DA PRECAUÇÃO - INVERSÃO DO ÔNUS DA PROVA. 1. A competência para o julgamento de execução fiscal por dano ambiental movida por entidade autárquica estadual é de competência da Justiça Estadual. 2. Não ocorre ofensa ao art. 535, II, do CPC, se o Tribunal de origem decide, fundamentadamente, as questões essenciais ao julgamento da lide. 3. O princípio da precaução pressupõe a inversão do ônus probatório, competindo a quem supostamente promoveu o dano ambiental comprovar que não o causou ou que a substância lançada ao meio ambiente não lhe é potencialmente lesiva. 4. Nesse sentido e coerente com esse posicionamento, é direito subjetivo do suposto infrator a realização de perícia para comprovar a ineficácia poluente de sua conduta, não sendo suficiente para torná-la prescindível informações obtidas de sítio da internet. 5. A prova pericial é necessária sempre que a prova do fato depender de conhecimento técnico, o que se revela aplicável na seara ambiental ante a complexidade do bioma e da eficácia poluente dos produtos decorrentes do engenho humano. 6. Recurso especial provido para determinar a devolução dos autos à origem com a anulação de todos os atos decisórios a partir do indeferimento da prova pericial. (STJ, $2^{\mathrm{a}}$ Turma, REsp n ${ }^{\mathrm{o}} 1060753$ - SP, Relatora Ministra Eliana Calmon, DJ. 01.12.2009).

Ementa: PROCESSUAL CIVIL E AMBIENTAL - AÇÃO CIVIL PÚBLICA - DANO AMBIENTAL - ADIANTAMENTO DE HONORÁRIOS PERICIAIS PELO PARQUET MATÉRIA PREJUDICADA - INVERSÃO DO ÔNUS DA PROVA - ART. $6^{\circ}$, VIII, DA LEI 8.078/1990 C/C O ART. 21 DA LEI 7.347/1985 - PRINCÍPIO DA PRECAUÇÃO. 1. Fica prejudicada o recurso especial fundado na violação do art. 18 da Lei 7.347/1985 (adiantamento de honorários periciais), em razão de o juízo de $1^{\circ}$ grau ter tornado sem efeito a decisão que determinou a perícia. 2. O ônus probatório não se confunde com o dever de o Ministério Público arcar com os honorários periciais nas provas por ele requeridas, em ação civil pública. São questões distintas e juridicamente independentes. 3. Justifica-se a inversão do ônus da prova, transferindo para o empreendedor da atividade potencialmente perigosa o ônus de demonstrar a segurança do emprendimento, a partir da interpretação do art. $6^{\circ}$, VIII, da Lei 8.078/1990 c/c o art. 21 da Lei 7.347/1985, conjugado ao Princípio Ambiental da Precaução. 4. Recurso especial parcialmente provido. (STJ, 2 ${ }^{\mathrm{a}}$ Turma, REsp n 972902 - RS, Relatora Ministra Eliana Calmon, DJ 25.08.2009).

Ementa: AÇÃO CIVIL PÚBLICA. DANO AMBIENTAL. AGRAVO DE INSTRUMENTO. PROVA PERICIAL. INVERSÃO DO ÔNUS. ADIANTAMENTO PELO DEMANDADO. DESCABIMENTO. PRECEDENTES.

I - Em autos de ação civil pública ajuizada pelo Ministério Público Estadual visando apurar dano ambiental, foram deferidos, a perícia e o pedido de inversão do ônus e das custas respectivas, tendo a parte interposto agravo de instrumento contra tal decisão. II - Aquele que cria ou assume o risco de danos ambientais tem o dever de reparar os danos causados e, em tal contexto, transfere-se 
cometeu o dano, mesmo que a conduta seja permitida, o sujeito causador terá de arcar com a reparação deste dano; ${ }^{159}$ (v) e por fim, a quinta consequência é a atenuação do relevo do nexo causal, não devendo ter uma grande preocupação em relacionar a atividade do agente com o prejuízo. ${ }^{160}$ e 161

Identifica-se na responsabilidade civil ambiental a função específica de servir para a reparação da lesão ambiental provocada, protegendo-se e conservando-se a qualidade do meio ambiente, independente da utilidade humana imposta ao bem no regime de apropriação públicos e privados, bem como, uma função social que ultrapassa as finalidades punitiva, preventiva e reparatória. $^{162}$

Os pressupostos desta responsabilidade objetiva são o evento danoso e o nexo causal, "não se investiga ação, conduta do poluidor/predador, pois o risco a ela substitui-se". 163

Evento danoso é a resultante da atividade que de forma direta ou indireta, cause lesão ao meio ambiente ou de seus componentes. Nexo de causalidade é a relação de causa e efeito entre a atividade e o dano dela advindo. $^{164}$

Porém o nexo de causalidade não é tão simples assim. O dano pode decorrer de várias causas distintas e concorrentes, simultâneas e sucessivas,

a ele todo o encargo de provar que sua conduta não foi lesiva. III - Cabível, na hipótese, a inversão do ônus da prova que, em verdade, se dá em prol da sociedade, que detém o direito de ver reparada ou compensada a eventual prática lesiva ao meio ambiente - artigo $6^{\circ}$, VIII, do CDC c/c o artigo 18, da lei ${ }^{\circ}$ 7.347/85. IV - Recurso improvido. (STJ, $1^{\text {a }}$ Turma, REsp n ${ }^{\circ} 1049822$ - RS, Relator Ministro Francisco Falcão, DJ 23.04.2009).

${ }^{159}$ Sobre esta quarta consequência, veja o que foi escrito na página 46 deste trabalho.

${ }^{160}$ FERRAZ, Sérgio. Op. cit., p. 38 - 40.

${ }^{161}$ Sobre a atenuação do relevo do nexo causal recomenda-se a leitura de acórdão da $2^{\mathrm{a}}$ Turma do STJ (Resp nº 650.728-SC, Relator Ministro Herman Benjamin, DJ 23.10.2007).

${ }^{162}$ STEIGLEDER, Annelise Monteiro. Op. cit., p. 188.

163 STEIGLEDER, Annelise Monteiro. Considerações sobre o Nexo de Causalidade na Responsabilidade Civil por Dano ao Meio Ambiente. Revista de Direito Ambiental. No. 32: p. 84. São Paulo: Revista dos Tribunais, 2003. 
sendo difícil possuir uma única e linear fonte; além do fato de que muitos danos ficam camuflados, ou só aparecem tardiamente, e de que existe uma dificuldade técnica e financeira para sua aferição.

Outra questão que ronda o nexo de causalidade ocorre com relação a qual teoria do risco é adotada na responsabilidade civil ambiental. Annelise Steigleder escreve sobre as duas principais teorias existentes:

De um lado a teoria do risco integral, mediante a qual todo e qualquer risco conexo ao empreendimento deverá ser integralmente internalizado pelo processo produtivo; e, de outro, a teoria do risco criado, a qual procura vislumbrar, dentre todos os fatores de risco, apenas aquele que, por apresentar periculosidade, é efetivamente apto a gerar as situações lesivas, para fins de imposição de responsabilidade. ${ }^{165}$

Em suma a teoria do risco integral não admite excludentes de responsabilidade, devendo o agente pelo simples fato de exercer uma dada atividade arcar com a reparação do dano oriundo da atividade, enquanto pela teoria do risco criado se o ato lesivo for decorrente de uma excludente de responsabilidade, não terá o sujeito econômico da atividade a obrigação de assumir a responsabilidade de reparação do dano ambiental. A teoria do risco integral é a mais aceita pela nossa doutrina ${ }^{166}$ e vem sendo consolidada pela nossa jurisprudência. ${ }^{167}$

\footnotetext{
${ }^{164}$ MILARÉ, Édis. Direito do Ambiente. $6^{a}$ ed. p. 958 e 960.

165 STEIGLEDER, Annelise Monteiro. Considerações sobre o Nexo de Causalidade na Responsabilidade Civil por Dano ao Meio Ambiente. p. 86.

${ }^{166}$ Esta é a posição dos doutrinadores Herman Benjamin, Jorge Nunes Athias, Sérgio Cavalieri Filho, Édis Milaré, Nelson Nery Junior, José Afonso da Silva, Sérgio Ferraz, Annelise Steigleder, dentre outros. (STEIGLEDER, Annelise Monteiro. Considerações sobre o Nexo de Causalidade na Responsabilidade Civil por Dano ao Meio Ambiente. Revista de Direito Ambiental. No. 32: 87. São Paulo: Revista dos Tribunais, 2003).

167 Ementa: ADMINISTRATIVO. DANO AMBIENTAL. SANÇÃO ADMINISTRATIVA. IMPOSIÇÃO DE MULTA. EXECUÇÃO FISCAL.

1. Para fins da Lei $n^{\circ} 6.938$, de 31 de agosto de 1981, art $3^{\circ}$, entende-se por: I - meio ambiente, o conjunto de condições, leis, influências e interações de ordem física, química e biológica, que permite, abriga e rege a vida em todas as suas formas; II - degradação da qualidade ambiental, a alteração adversa das características do meio ambiente; III - poluição, a degradação da qualidade ambiental resultante de atividades que direta ou indiretamente: a) prejudiquem a saúde, a segurança e o bem-estar da população; b) criem condições adversas às atividades sociais e econômicas; c) afetem desfavoravelmente a biota; d) afetem as condições estéticas ou sanitárias do meio ambiente; e) lançem matérias ou energia em desacordo com os padrões ambientais estabelecidos; 2. Destarte, é poluidor a pessoa física ou jurídica, de direito público ou privado,
} 
Outra característica da responsabilidade ambiental é a solidariedade, "havendo mais de um empreendedor, prevalece entre eles o vínculo e as regras da solidariedade". ${ }^{168}$ Isso porque, uma das maiores dificuldades do direito ambiental é justamente delimitar precisamente de quem partiu a atividade lesiva, principalmente quando existe um conglomerado de atividades poluidoras atuando no mesmo local, sem ter como determinar qual das atividades provocou o dano.

responsável, direta ou indiretamente, por atividade causadora de degradação ambiental; 3. O poluidor, por seu turno, com base na mesma legislação, art. 14 - "sem obstar a aplicação das penalidades administrativas" é obrigado, "independentemente da existência de culpa", a indenizar ou reparar os danos causados ao meio ambiente e a terceiros, "afetados por sua atividade". 4. Depreende-se do texto legal a sua responsabilidade pelo risco integral, por isso que em demanda infensa a administração, poderá, inter partes, discutir a culpa e o regresso pelo evento. 5. Considerando que a lei legitima o Ministério Público da União e do Estados terá legitimidade para propor ação de responsabilidade civil e criminal, por danos causados ao meio ambiente, é inequívoco que o Estado não pode inscrever sel-executing, sem acesso à justiça, quantum indenizatório, posto ser imprescindível ação de cognição, mesmo para imposição de indenização, o que não se confunde com a multa, em obediência aos cânones do devido processo legal e da inafastabilidade da jurisdição. 6. In casu, discute-se tão-somente a aplicação da multa, vedada a incursão na questão da responsabilidade fática por força da Súmula 07/STJ. 5. Recurso improvido. (STJ, $1^{\text {a }}$ Turma, REsp no 442586 - SP, Relator Ministro Luiz Fux, DJ. 26.11.2002). (original sem grifos)

Ementa: DANO AMBIENTAL. DERRAMAMENTO DE ENTULHO. RESPONSABILIDADE OBJETIVA. TEORIA DO RISCO INTEGRAL. MULTA. PODER DE POLICIA

Apelação Cível. Dano ambiental. Derramamento de entulho do Rio Faria Timbó. Em matéria que envolve direito ambiental, vige o princípio da responsabilidade objetiva, em que é suficiente comprovar a existência do fato e o nexo causador do dano ambiental, sendo desnecessário indagar a propósito da culpa, simplesmente, porque esta decorre da lei e da atividade exercida pela autora. Adoção da Teoria do Risco Integral, especialmente em face do tratamento constitucional da matéria, que parece ter criado verdadeira obrigação de incolumidade sobre os bens ambientais. Por esta teoria, não se admitem excludentes de responsabilidade, tais como caso fortuito, força maior, ação de terceiros ou da própria vítima, bastando, como já se referiu, a relação de causa e efeito entre uma conduta do poluidor e os prejuízos então advindos. $\mathrm{O}$ dano restou evidenciado de forma indiscutível. A alegada coação não é meio capaz de desconstituir a infração e, mesmo se comprovada, não excluiria a responsabilidade que, in casu, é objetiva e integral. Acrescente-se que o procedimento administrativo foi claro e categórico em informar a prática da irregularidade que gerou a aplicação da penalidade pela administração. Isto se extrai, sem maiores dificuldades, do inquérito civil acostado aos autos. Portanto, não há motivo para que se desconstitua o auto de infração que culminou na aplicação da multa que, aliás, como espécie de ato administrativo, é dotada do atributo da presunção de legitimidade. É certo que não se trata de presunção absoluta e intocável. A hipótese é de presunção relativa que pode ceder à prova em contrário, no sentido de que o ato não se conformou às regras que lhe traçavam, porém o apelante não se desincumbiu deste ônus. Negado provimento ao recurso. (TJRJ, $4^{\mathrm{a}}$ Câmara Civel, AP $\mathrm{n}^{\circ}$ 0042446-69.2007.8.19.0001, Relator Desembargadora Monica Tolledo de Oliveira, DJ. 15.12.2009). (original sem grifos).

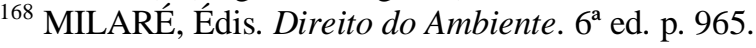


Não existe diferença de aplicação da responsabilidade civil ambiental em função da atividade que causou o dano, em todos os casos os pressupostos acima explicados serão aplicados. Vale frisar que com relação à atividade de E\&P a responsabilidade civil aplicada também é objetiva e solidária, e deve ser respeitado o regime jurídico acima exposto.

\section{4 - Responsabilidade civil e o contrato de concessão}

De forma a fortalecer a responsabilidade civil ambiental do sujeito econômico que explora a atividade de E\&P, vale citar ainda os dispositivos da lei do petróleo e do contrato de concessão, os quais prevêem a responsabilidade civil objetiva do concessionário.

$\mathrm{O}$ art. 44 da Lei Federal $n^{\circ}$ 9.478/97 determina que o contrato de concessão estabeleça que o concessionário é responsável civilmente por quaisquer danos decorrentes das atividades de exploração, desenvolvimento e produção, vejamos:

Art. 44. O contrato estabelecerá que o concessionário estará obrigado a:

$(\ldots)$

V - responsabilizar-se civilmente pelos atos de seus prepostos e indenizar todos e quaisquer danos decorrentes das atividades de exploração, desenvolvimento e produção contratadas, devendo ressarcir à ANP ou à União os ônus que venham a suportar em consequiência de eventuais demandas motivadas por atos de responsabilidade do concessionário;

Maria Menezello entende que o mencionado dispositivo trata a responsabilidade civil do concessionário como objetiva, in verbis:

No entanto, da interpretação sistemática desse inciso, declarado como cláusula essencial do contrato de concessão, verificamos que a escolha do legislador foi por qualificar esta responsabilidade como objetiva, determinando sua inclusão no contrato que integra o edital para escolha do concessionário. ${ }^{169}$

Por sua vez, o contrato de concessão prevê que o concessionário é o responsável exclusivo por todos os riscos relacionados com a execução da 
atividade. É o que encontramos no parágrafo 2.2, da Cláusula Segunda do Modelo do Contrato de Concessão da Rodada 10:

2.2 O Concessionário assumirá sempre, em caráter exclusivo, todos os custos e riscos relacionados com a execução das Operações e suas conseqüências, cabendo-lhe, como única e exclusiva contrapartida, a propriedade do Petróleo e Gás Natural que venham a ser efetivamente produzidos e por ele recebidos no Ponto de Medição da Produção, nos termos deste Contrato, com sujeição aos encargos relativos aos tributos e às compensações financeiras detalhadas no ANEXO V - Participações Governamentais e de Terceiros, e da legislação brasileira aplicável. ${ }^{170} \mathrm{e} 171$

Por fim, o parágrafo 13.1, da Cláusula Décima Terceira do Modelo de Contrato de Concessão, dispõe claramente que a responsabilidade do agente explorador da atividade de E\&P ocorre independentemente da existência de culpa, ou seja, a responsabilidade é objetiva, nestes termos:

13.1 Durante a vigência deste Contrato, e desde que observados os termos e condições do mesmo, o Concessionário terá, com a exceção prevista no parágrafo 2.6, o direito exclusivo de realizar as Operações na Área da Concessão, obrigando-se para isso, por sua conta e risco, a aportar todos os investimentos e a arcar com todos os gastos necessários, a fornecer todos os equipamentos, máquinas, pessoal, serviços e tecnologia apropriados, e a assumir e responder integral e objetivamente pelas perdas e danos causados, direta ou indiretamente, pelas Operações e sua execução, independentemente da existência de culpa, tanto a terceiros quanto à ANP e à União, de acordo com os parágrafos 2.2, 2.3 e demais disposições aplicáveis deste Contrato. ${ }^{172}$

Em face dos dispositivos expostos, pode-se deduzir que tanto a lei que regula a atividade quanto o contrato de concessão possuem a preocupação em delimitar a responsabilidade civil que envolve os danos oriundos da atividade proveniente da indústria petrolífera, em vista da

\footnotetext{
${ }^{169}$ MENEZELLO, Maria D’Assunção Costa. Op. cit., p 135.

170 Modelo de Contrato de Concessão da Rodada 10, encontrado em: <http://www.brasilrounds.gov.br/arquivos/Editais/Modelo_Contrato_R10_\%2030Out08.pdf>. Acesso em $27 \mathrm{de}$ setembro de 2010. (original sem grifos)

${ }^{171}$ Ao citar esse dispositivo, visa-se tão somente demonstrar que o Modelo de Contrato de Concessão da Rodada 10 também prevê a responsabilidade do concessionário, não tendo como este se eximir da mesma. Sendo assim, cumpre ressaltar que, não é objetivo deste estudo verificar e falar sobre a legalidade da imposição exclusiva de responsabilidade ao concessionário, eximindo o poder público, esta é uma discussão que vai além do tema proposto.

${ }_{172}$ Modelo de Contrato de Concessão da Rodada 10, encontrado em: <http://www.brasilrounds.gov.br/arquivos/Editais/Modelo_Contrato_R10_\%2030Out08.pdf>. Acesso em $27 \mathrm{de}$ setembro de 2010. (original sem grifos)
} 
complexidade que estes danos podem apresentar. A responsabilidade aqui tratada não se restringe a responsabilidade ambiental, porém a incorpora.

Ressalta-se que a responsabilidade civil ambiental da atividade em questão é regida essencialmente pelos preceitos expostos do item anterior (3.3), porém a responsabilidade como se encontra delimitada na lei do petróleo e no contrato de concessão também influencia na caracterização da responsabilidade civil ambiental das concessionárias de E\&P.

\section{5 - O caso da British Petroleum (BP) e suas consequências}

Por fim, vale fazer uma breve exposição sobre o mais recente e drástico desastre ambiental envolvendo atividade de E\&P, oriundo do vazamento de petróleo da plataforma Deepwater Horizon da BP no Golfo do México.

O acidente ocorreu no dia 20 de abril de 2010, resultou em 11 mortes de trabalhadores, despejou cerca de 5 milhões de barris de petróleo no mar, contaminando quilômetros de costas dos Estados Unidos, e causou e causará, durante muito tempo, forte impacto no ecossistema marinho existente ao redor, além de atingir a comunidade local e atividades econômicas dependentes dos recursos naturais atingidos.

Um especial aspecto assustou a toda comunidade mundial que se viu durante quase 4 meses sem uma resposta para o vazamento que, ressalta-se, só foi contido no dia 15 de julho de 2010, ou seja, 86 dias após o desastre: ${ }^{173}$ o quanto é segura a atividade de E\&P offshore?

Em reportagem do jornal O Estado de São Paulo, o secretário de Petróleo, Gás natural e Combustíveis Renováveis do Ministério de Minas e

\footnotetext{
${ }^{173}$ Dados retirados da reportagem: BP veda poço cinco meses após maior desastre ambiental dos EUA: Vazamento do Golfo do México atinge 4 milhões de barris. Empresa perde US\$ 87 bi. $O$ Globo, Rio de Janeiro, p. 18, 20.09.2010.
} 
Energia, Marco Antônio Martins Almeida, afirma que "As falhas que sabemos com certeza que aconteceram lá não deveriam acontecer aqui", ${ }^{174}$ "Temos procedimentos e métodos de fiscalização que permitiriam evitar que aquilo acontecesse" ${ }^{175}$, observando que boa parte do acidente ainda precisa ser investigado. Destaca-se ainda da reportagem:

"Há uma diferença grande entre Brasil e os Estados Unidos", disse Almeida. Aqui a Agência Nacional do Petróleo (ANP) estabelece normas de segurança para a exploração de petróleo. Lá, esses procedimentos ficam a critério de cada empresa. (...) Os BOPs utilizados no Brasil são mais seguros do que o de Macondo, porque têm duas "gravetas". Se uma delas falhar ao fechar o poço, como ocorreu nos EUA, a outra entrará em ação. A ANP exige também que os BOPs tenham dois comandos para fechar. (...) Os procedimentos do Brasil e da Noruega são citados pelos especialistas em todo o mundo como exemplos a serem seguidos. As medidas preventivas evoluíram aqui à custa de três acidentes: dois na plataforma de Enchova (em 1984 e 1988) e um na P-36 (2001). ${ }^{176}$

Existem dados extremamente técnicos nesta reportagem, mas uma coisa pode-se concluir juntamente com o que foi apresentado neste trabalho: o Brasil realmente possui instrumentos de fiscalização, órgãos atuantes (ANP, IBAMA e Marinha), licenças ambientais, estudos pertinentes à matéria e legislação extensa sobre a atividade e seu modo de exploração e produção - levando em consideração a matéria ambiental -, além do instituto da responsabilidade civil para reparar os danos provocados. Porém, conforme já fora citado, "por melhores que sejam a prevenção e a precaução, danos ambientais ocorrerão na medida em que os 'acidentes são normais em qualquer atividade'", ${ }^{177}$

Fato é que o acidente em comento provocou uma onda de temor não só na sociedade, mas também nas demais petrolíferas, que não querem ser pegas de surpresa com um desastre de tamanha proporção e seu consequente custo econômico. No Brasil, como já foi falado, está sendo

\footnotetext{
${ }^{174}$ OTTA, Lu Aiko; ANDRADE, Renato. Acidente da BP seria evitado no Brasil. O Estado de São Paulo, São Paulo, p. B4, 09.08.2010.

${ }^{175}$ Ibid. p. B4.

${ }^{176}$ Ibid. p. B4.

${ }^{177}$ BENJAMIM, Antônio Herman. Responsabilidade civil pelo dano ambiental. p. 9.
} 
elaborado - impulsionado pelo acidente - o Plano Nacional de Contingência, previsto na Lei Federal no 9.966, desde 2000 e nunca criado. Os investidores começam a pressionar e exigem que as empresas tornem públicos os seus planos de emergências para vazamentos. ${ }^{178}$ Pesquisas preventivas se intensificam com a finalidade de evitar desastres semelhantes ao ora narrado. ${ }^{179}$

Verifica-se que, como tudo no direito ambiental, encontra-se neste caso um embate econômico e ambiental, em que, de um lado, temos o crescente desenvolvimento da indústria petrolífera no país e no mundo, principalmente com a descoberta e começo da exploração do Pré-sal, propiciando o crescimento do mercado financeiro brasileiro e a utilização da energia advinda do petróleo e, de outro lado, tem-se as consequências ambientais advindas da atividade, como o caso da BP.

Ponderar os riscos e benefícios da atividade é uma tarefa que vai além dos objetivos deste trabalho. Direito econômico e direito ambiental devem caminhar lado-a-lado, e ambos são importantes para a sociedade mundial. Medidas drásticas para ambos os lados não são respostas adequadas.

Vale citar Cristiane Derani, ao falar sobre o direito econômico e sobre o direito ambiental:

\begin{abstract}
A aceitação de que a qualidade de vida corresponde tanto a um objetivo do processo econômico como a uma preocupação da política ambiental afasta a visão parcial de que as normas de proteção do meio ambiente seriam servas da obstrução de processos econômicos e tecnológicos. A partir deste enfoque, tais normas buscam uma compatibilidade desses processos com as novas e sempre crescentes exigências do meio ambiente.
\end{abstract}

\footnotetext{
${ }^{178}$ Investidor pede plano de ação para vazamentos de petróleo. Valor Econômico, São Paulo, p. A11, 06.08.2010.

${ }_{179}$ Vamos Combinar: Noruegueses fazem pesquisa preventiva. Época, Rio de Janeiro, p. 44, 26/09/2010, e Shell desenvolve fluidos de perfuração para operações em águas ultraprofundas. $T N$ Petróleo - Produtos \& Serviços, Rio de Janeiro, p. 180, julho/agosto de 2010.
} 
A Constituição Federal brasileira contém este caráter integrador da ordem econômica com a ordem ambiental, unidas pelo elo comum da finalidade de melhoria da qualidade de vida. ${ }^{180}$

Desta forma, a produção energética é fator essencial para a qualidade de vida da sociedade, e enquanto não se encontrar plenamente desenvolvida e implementada uma forma mais segura de produção de energia a exploração da atividade petrolífera também se faz essencial para a coletividade.

Mister observar que a indústria petrolífera deve respeitar as normas ambientais e ser severamente fiscalizada, para tentar evitar ao máximo que acidentes como o da BP voltem a ocorrer. Da mesma forma, é importante que a nossa matriz energética comece a ser substituída de forma racional e segura para outras fontes de energia sustentáveis e que promovam impactos menores no meio ambiente.

${ }^{180}$ DERANE, Cristiane. Op. cit., p. 60. 


\section{Conclusão}

Diante do mencionado acidente envolvendo a British Petroleum constatamos o quanto estamos vulneráveis em razão do avanço da atividade petrolífera e que a matéria ambiental precisa ser observada atentamente na execução desta atividade, de forma a minimizar os riscos e torná-los no mínimo aceitáveis. Paulo Bessa, ao introduzir o capítulo de seu livro, Direito Ambiental: Amplamente Reformulado, sobre responsabilidade ambiental, expõe:

No caso do Direito Ambiental, a sua existência somente se justifica se ele for capaz de estabelecer mecanismos aptos a intervir no mundo econômico de forma a fazer com que ele não produza danos ambientais além daqueles já julgados socialmente suportáveis. Quando tais limites são ultrapassados, necessário se faz que os responsáveis pela ultrapassagem sejam responsabilizados e arquem com os custos decorrentes de suas condutas ativas ou omissivas. Tal sistema de imposição de custos, sejam eles financeiros, morais ou políticos, é o que se chama de responsabilidade. ${ }^{181}$

Considerando que "O direito é fundamentalmente uma orientação do comportamento coletivo, aonde vão nutrir-se as relações contratuais privadas", ${ }^{182}$ foi feito um estudo com a finalidade de trazer os principais conceitos jurídicos ambientais pertinentes à atividade de E\&P de petróleo e seu impacto ao meio ambiente. Vale destacar a explicação de Cristiane Derani:

Assim políticas que reencontrem uma compatibilização da atividade econômica com o aumento das potencialidades do homem e do meio natural, sem exauri-las; apoiadas por normas de incentivo à pesquisa científica de proteção dos recursos naturais e de garantia de uma qualidade ambiental, são expressões do direito ao desenvolvimento sustentável - uma outra forma de ver e compreender o direito ambiental. $^{183}$

Tendo como base uma breve análise dos aspectos gerais da atividade em questão, tais como conceito, histórico, legislação aplicável e órgãos

\footnotetext{
${ }^{181}$ ANTUNES, Paulo Bessa. Direito Ambiental: Amplamente Reformulado. 11 a ed. p.201.

${ }^{182}$ DERANE, Cristiane. Op. cit., p. 135.

${ }^{183}$ Ibid. p. 156.
} 
atuantes, observou-se que a abertura do mercado de petróleo é relativamente recente (ocorreu após a Emenda Constitucional $n^{\circ}$ 09/95) e por isso, a legislação ambiental aplicável ao tema, também é recente, uma vez que quando a atividade era controlada pela Petrobrás, não havia regulamentação específica sobre a matéria e tudo era desenvolvido e aplicado pela própria empresa de economia mista.

Notou-se que o trabalho de fiscalização da execução da atividade deve ser feito em conjunto entre a agência reguladora da indústria do petróleo, a Marinha do Brasil, os órgãos ambientais, em especial o IBAMA. Falou-se de um importante instrumento existente para a fiscalização e implementação dos princípios ambientais da precaução, prevenção e desenvolvimento sustentável, que é o Plano Nacional e Contingência, o qual ainda não foi regulamentado, porém já possui previsão legal para sua criação desde 2000 .

Em seguida, tratou-se dos aspectos do licenciamento ambiental, em especial do seu caráter preventivo, o que o torna um dos instrumentos mais importantes para a consecução da proteção do meio ambiente. Falou-se, também, da Avaliação de Impacto Ambiental, "responsável por estratégias preventivas e antecipadoras da política ambiental". ${ }^{184}$

Observou-se que o licenciamento ambiental de petróleo e gás é específico, considerando suas peculiaridades, o que me parece ser um avanço, pois se torna mais eficaz ao conjugar diferentes avaliações de impacto ambiental, conforme a gravidade da atividade que está sendo desenvolvida em cada momento da exploração, além de garantir um procedimento mais célere, propiciando a conjugação do direito ambiental como o direito econômico.

${ }^{184}$ Ibid. p. 157. 
Verificou-se, ainda, que, os danos ambientais provocados pela indústria petrolífera no mar é um dos mais impactantes ao meio ambiente, além de ser de difícil recuperação, porém, estes atos lesivos acontecem e a sociedade está vulnerável quanto a isto, podem ser evitados pelo uso da precaução e da prevenção, mas é impossível impedi-los, até porque na maioria das vezes são inesperados, a não ser quando o responsável agiu negligentemente.

Sendo assim, o instituto da responsabilidade civil ambiental, ao lado do licenciamento e da avaliação de impacto ambiental, é um instrumento eficaz para realizar a reparação ambiental, e sua consequente proteção. Verificou-se que não existe uma responsabilidade civil ambiental específica para E\&P de petróleo, porém o contrato de concessão e a legislação reguladora da atividade fortalecem o instituto ambiental.

O direito ambiental brasileiro encontra-se, portanto, bem estruturado para atender as exigências impostas para a proteção do meio ambiente. Diante das consequências do acidente da BP, espera-se que surja um impacto positivo em toda sociedade, incluindo o Brasil, tornando a maioria das empresas conscientes e preocupadas em proteger o meio ambiente e não deixar que um novo desastre como o mencionado volte a acontecer. Édis Milaré destaca que:

E assim chegamos ao estado atual, em que nossas ações chocam-se contra nossos deveres e direitos, comprometendo nosso próprio destino. O renomado historiador H.G. Wells registrou: 'A história humana é cada vez mais uma corrida entre a educação e o desastre'. Este é o paradoxo existente nas relações do homem com a Terra. (...)

A vigilância ambiental, inclusive a consciência jurídico-ecológica, deve estar atenta ao que é patente e ao que esta latente, tanto aos riscos e delitos existentes e reais como àqueles potenciais e futuros. ${ }^{185}$

${ }^{185}$ MILARÉ, Édis. Direito do Ambiente. $6^{\text {a }}$ ed. p. 58. 
Por fim, cumpre afirmar que atividade em questão é muito perigosa e quando provoca um acidente tem impactos gigantescos para o meio ambiente, logo, faz-se necessário que a base energética brasileira e mundial, seja paulatinamente modificada para uma energia mais segura e menos degradadora dos recursos naturais. 


\section{Referências Bibliográficas}

ANTUNES, Luiz Felipe Colaço. O procedimento administrativo de avaliação de impacto ambiental: para uma tutela preventiva do ambiente. Coimbra, Almedina, 1998.

ANTUNES, Paulo Bessa. Dano ambiental: Uma Abordagem Conceitual. Rio de Janeiro: Lumen Juris. 2000.

- Proteção Ambiental nos Atividades de Exploração e

Produção de Petróleo: Aspectos Jurídicos. Rio de Janeiro: Lumen Juris, 2003.

Direito Ambiental: Amplamente Reformulado. $11^{\mathrm{a}}$ ed. Rio de Janeiro: Lumen Juris, 2008.

BP culpa parceiras por vazamento de plataforma: Empresa indica falhas de subcontratadas em desastre no Golfo do México. Folha de São Paulo, São Paulo, p. A10, 09.09.2010.

BP veda poço cinco meses após maior desastre ambiental dos EUA: Vazamento do Golfo do México atinge 4 milhões de barris. Empresa perde US\$ 87 bi. $O$ Globo, Rio de Janeiro, p. 18, 20.09.2010.

BENJAMIN, Antônio Herman. Responsabilidade civil pelo dano ambiental. Revista de Direito Ambiental. São Paulo: Revista dos Tribunais, n. 09, p. 5 $-52,1998$.

Introdução ao Direito Ambiental Brasileiro.

Revista de Direito Ambiental. São Paulo:Revista dos Tribunias, v. 14, ano 4, p. 48 - 82, abril-junho, 1999.

BEZERRA, Luiza Cavalcanti. O licenciamento ambiental e a desinstalação de operações de petróleo e gás natural no Brasil. Revista do Direito da Energia. São Paulo: Ibde, n. 07, p. 13 - 53, 2008. 
BUCHEB, José Alberto. Direito do petróleo: a regulação das atividades de exploração e produção de petróleo e gás natural no Brasil. Rio de Janeiro: Lumen Juris, 2007.

DERANE, Cristiane. Direito Ambiental Econômico. $3^{\mathrm{a}}$ ed, São Paulo: Saraiva, 2008.

ENNES, Juliana. Plano de contingência sai até setembro. Valor Econômico, São Paulo, p. B7, 27.07.2010.

FERNANDES DA SILVA, Eduardo. Análise crítica do licenciamento ambiental de pesquisas sísmicas terrestres no Brasil. Disponível em <http://www.nitsustentabilidade.org/Portals/2/documents/cneg5/anais/T8 0 144_0715.pdf>. Acesso em 11 de outubro de 2010.

FERRAZ, Sérgio. Responsabilidade civil por dano ecológico. Revista de Direito Público. São Paulo: Revista dos Tribunais, n. 49/90, p. 34 - 41, 1979.

FREITAS, Vladimir Passos de. A Constituição Federal e a Efetividade das Normas Ambientais. $3^{\mathrm{a}}$ ed. São Paulo: Revista dos Tribunais. 2005.

Investidor pede plano de ação para vazamentos de petróleo. Valor Econômico, São Paulo, p. A11, 06.08.2010.

LOBÃO, Edson et al.. Exposição de Motivos E.M.I. n ${ }^{\mathbf{o}} 00038$ MME/MF/MDIC/MP/CCIVIL de 31.08.2009.

Exposição de Motivos E.M.I. n n 119 MF/MME/MP/MDIC/CCIVIL de 31.08.2009.

MACHADO, Paulo Affonso Leme. O Princípio da Precaução e o Direito Ambiental. Revista de Direitos Difusos. São Paulo: Adcoas, v.8, p. 1081 1093, 2001. 
- O Princípio da Precaução e a avaliação de riscos. Revistas dos Tribunais. São Paulo: Revistas dos Tribunais, v. 856, ano96, p. 35 - 50, fev. 2007.

. Direito Ambiental Brasileiro. $17^{\mathrm{a}}$ ed. São Paulo:

Malheiros Editores, 2009.

MELLO, Celso A. Algumas considerações sobre o petróleo e a ordem internacional. In: ROSADO, Marilda (Org.). Estudos e pareceres: direito do petróleo e gás. Rio de Janeiro: Renovar, 2005.

MELLO, Marcelo de Oliveira. Experiência brasileira nos contratos de produção de petróleo. Revista do Direito da Energia. São Paulo: Ibde, n. 01, p. 41 - 47, 2004.

MENEZELlO, Maria D’Assunção Costa. Comentários à Lei do Petróleo: Lei Federal no 9.478, de 6-8-1997. São Paulo: Atlas, 2000.

MILARÉ, Édis. Direito do Ambiente. $4^{\mathrm{a}}$ ed. São Paulo: Revista dos Tribunais, 2005.

Direito do Ambiente. $6^{\mathrm{a}}$ ed. São Paulo: Revista dos

Tribunais, 2009.

MIRRA, Álvaro Luiz Valery. Princípios Fundamentais do Direito Ambiental. In: Revista de Direito Ambiental. №. 2. p. 50 - 56. São Paulo: Revista dos Tribunais, 1996.

- Ação Civil Pública e a Reparação do Dano ao

Meio Ambiente. $2^{\mathrm{a}}$ ed. São Paulo: Editora Juarez de Oliveira, 2004.

Modelo de Contrato de Concessão da Rodada 10. Disponível em: $<$ http://www.brasil- 
rounds.gov.br/arquivos/Editais/Modelo_Contrato_R10_\%20300ut08.pdf> Acesso em 27 de setembro de 2010.

NETO, Nicolao Dino de C. Costa. Aspectos da tutela preventiva do meio ambiente: avaliação de impacto ambiental e licenciamento ambiental. In: LEITE, José Rubens Morato; BELLO FILHO, Ney de Barros (Org.). Direito Ambiental Contemporâneo. São Paulo: Manole, 2004.

ORDOÑEZ, Romana, Um plano nacional contra vazamento: Três meses após desastre nos EUA, ANP, Marinha e Ibama elaboram programa de ação para acidentes do pré-sal. $O$ Globo, Rio de Janeiro, p. 19, 26.07.2010.

OTTA, Lu Aiko; ANDRADE, Renato. Acidente da BP seria evitado no Brasil. O Estado de São Paulo, São Paulo, p. B4, 09.08.2010.

QUINTAS, Luiz Cezar P.; QUINTAS, Humberto. A História do Petróleo no Brasil e no Mundo. Rio de Janeiro: Freitas Bastos Editora, 2005.

RIBEIRO, Marilda Rosado de Sá. Direito do petróleo: as joint ventures na indústria do petróleo. 2. ed. Rio de Janeiro: Renovar, 2003.

. O futuro do petróleo - perspectivas jurídicas.

Revista do Direito da Energia. São Paulo: Ibde, n. 03, p. 61 - 78, 2005.

"Royalties" do Petróleo, Disponível em <http://www.mar.mil.br/menu v/ccsm/temas relevantes/royalties mb.htm> Acesso em 06 de setembro de2010.

Shell desenvolve fluidos de perfuração para operações em águas ultraprofundas. TN Petróleo - Produtos \& Serviços, Rio de Janeiro, p. 180, julho/agosto de 2010.

STEIGLEDER, Annelise Monteiro. Considerações sobre o Nexo de Causalidade na Responsabilidade Civil por Dano ao Meio Ambiente. 
Revista de Direito Ambiental. No. 32, p. 83 - 103. São Paulo: Revista dos Tribunais, 2003.

Responsabilidade Civil Ambiental: as dimensões do dano ambiental no direito brasileiro. Porto Alegre: Livraria do Advogado Editora, 2004.

STF, ADI n ${ }^{\circ}$ 3.273, Rel. Ministro Carlos Brito e Ministro Eros Grau, DF, DJ. 16.03.2005.

STJ, $1^{\text {a }}$ Turma, REsp no 442586 - SP, Relator Ministro Luiz Fux, DJ. 26.11.2002.

STJ, $1^{\text {a }}$ Turma, REsp no 1049822 - RS, Relator Ministro Francisco Falcão, DJ 23.04.2009.

STJ, 2 $2^{\text {a Turma, REsp n }} 972902$ - RS, Relatora Ministra Eliana Calmon, DJ 25.08.2009.

STJ, 2 ${ }^{\text {a }}$ Turma, REsp n 1060753 - SP, Relatora Ministra Eliana Calmon, DJ. 01.12.2009.

TJRJ, 12ª Câmara Cível, AP no 2002.001.15693, Rel. Francisco de Assis Pessanha, DJ. 10.12.2002.

TJRJ, 13ª Câmara Cível, AP no 2005.001.44143, Rel. Nametala Machado Jorge, DJ. 28.06.2006.

TJRJ, 4 ${ }^{\mathrm{a}}$ Câmara Cível, AP $\mathrm{n}^{\mathrm{o}}$ 0042446-69.2007.8.19.0001, Relator Desembargadora Monica Tolledo de Oliveira, DJ. 15.12.2009.

TJRS, Turma Recursal Criminal, RC $\mathrm{n}^{\circ}$ 71002618288, Relatora Desembargadora Cristina Pereira Gonzales, Porto Alegre, DJ. 28.06.2010. 
TRF 1 ${ }^{a}$ Região, MS n 2003.34.00.000362-8, Rel. Desembargadora Federal Selene Maria de Almeida, DF, DJ. 13.12.2004.

Vamos Combinar: Noruegueses fazem pesquisa preventiva. Época, Rio de Janeiro, p. 44, 26/09/2010. 